NASA/TM-1998-206616

(2)

Physical Mechanisms of Glaze Ice Scallop Formations on Swept Wings

\author{
Mario Vargas \\ Lewis Research Center, Cleveland, Ohio \\ Eli Reshotko \\ Case Western Reserve University, Cleveland, Ohio
}

Prepared for the

36th Aerospace Sciences Meeting \& Exhibit

sponsored by the American Institute of Aeronautics and Astronautics

Reno, Nevada, January 12-15, 1998

National Aeronautics and

Space Administration

Lewis Research Center 
Available from

NASA Center for Aerospace Information 800 Elkridge Landing Road

Linthicum Heights, MD 21090-2934

Price Code: A03

National Technical Information Service 5287 Port Royal Road Springfield, VA 22100 Price Code: $\mathrm{A} 03$ 


\title{
PHYSICAL MECHANISMS OF GLAZE ICE SCALLOP FORMATIONS ON SWEPT WINGS
}

\author{
Mario Vargas \\ NASA Lewis Research Center, Cleveland, Ohio \\ and \\ Eli Reshotko' \\ Case Western Reserve University, Cleveland, Ohio
}

\begin{abstract}
An experiment was conducted to understand the physical mechanisms that lead to the formation of scallops on swept wings. Icing runs were performed on a NACA 0012 swept wing tip at $45^{\circ}, 30^{\circ}$, and $15^{\circ}$ sweep angles. A baseline case was chosen and direct measurements of scallop height and spacing, castings, video data and close-up photographic data were obtained. The results showed the scallops are made of glaze ice feathers that grow from roughness elements that have reached a minimum height and are located beyond a given distance from the attachment line. This distance depends on tunnel conditions and sweep angle, and is the critical parameter in the formation of scallops. It determines if complete scallops, incomplete scallops or no scallops are going to be formed. The mechanisms of growth for complete and incomplete scallops were identified. The effect of velocity, temperature and LWC on scallop formation was studied. The possibility that cross flow instability may be the physical mechanism that triggers the growth of roughness elements into glaze ice feathers is examined.
\end{abstract}

\section{Nomenclature}

$\Lambda \quad$ Sweep angle, degrees

LWC Cloud liquid water content, $\mathrm{g} / \mathrm{m}^{3}$

MVD Water droplet median volume diameter, $\mu \mathrm{m}$

$R \quad$ Attachment line Reynolds number

\footnotetext{
Aerospace Engineer, Icing Branch, NASA Lewis Research Center

† Professor, Department of Mechanical and Aerospace Engineering, Fellow, AIAA
}

Copyright 1998 by the American Institute of Aeronautics and Astronautics, Inc. No copyright is asserted in the United States under Title 17, U.S. Code. The U.S. Government has a royalty-free license to exercise all rights under the copyright claimed herein for Governmental Purposes. All other rights are reserved by the copyright owner. $r \quad$ Leading edge radius of airfoil, $m$

$\tau \quad$ Ice accretion time, minutes

$v_{e} \quad$ Kinematic viscosity at boundary layer edge, $\mathrm{m}^{2} / \mathrm{s}$

$U_{s} \quad$ Chordwise velocity at boundary layer edge, $\mathrm{m} / \mathrm{s}$

$V_{\infty} \quad$ Free stream velocity, $\mathrm{m} / \mathrm{s}$

\section{Introduction}

An understanding of the fundamental physical mechanisms that lead to the formation of the ice accretions known as scallops or lobster tails is one of the areas of research in the Icing Branch at NASA Lewis Research Center. These ice accretions appear only on swept wings for certain conditions that favor glaze ice formations, and are characterized by a particular shape, height, and spacing. Studies of scallop formations on swept wings are needed to provide the fundamental data for the development of models that can be implemented into 3D ice accretion codes.

The presence of scallop formations on swept wings has been documented in past studies of ice accretions on swept wings ${ }^{1,2,3}$. Initial work to predict scallop formations using a 3D ice accretion code was done by Reehorst". LEWICE 3D was modified and code predictions were compared to ice accretion flight data. An experiment in the NASA Lewis Icing Research Tunnel (IRT) to study the effect of tunnel parameters on the presence or absence of scallops was done by Reehorst and Bidwell. . A ballistic model of scallop growth was proposed by Hedde and Guffond ${ }^{6}$. Efforts to model scallop formations have been hampered because it is not known how the scallops actually form.

This report presents the results of an experimental investigation carried out in the lcing Research Tunnel (IRT) at NASA Lewis Research Center to understand the basic physical mechanisms involved in the 
formation of scallops or lobster tails. To study the physical mechanisms involved in their formation, icing runs were performed using a NACA 0012 swept wing tip that could be set at $0^{\circ}, 15^{\circ}, 30^{\circ}$, or $45^{\circ}$ angles of sweep. A base case was chosen to study the time history of scallop formation. The conditions for the base case were $45^{\circ}$ sweep angle, a free stream speed of $150 \mathrm{mph}$, a tunnel temperature of $25^{\circ} \mathrm{F}, 0.75 \mathrm{~g} / \mathrm{m}^{3}$ LWC and $20 \mu \mathrm{m}$ MVD. Direct measurements of scallop height and spacing, castings, video data and close-up photographic data were obtained. For comparison with the base case, tests were run at sweep angles of $30^{\circ}$ and $15^{\circ}$ for the same conditions as the base case. Additional icing runs were carried out for sweep angles of $45^{\circ}, 30^{\circ}$, and $15^{\circ}$, to study the velocity effect, the temperature effect, and the LWC effect on the formation of the scallops. For a $15^{\circ}$ sweep angle at the base conditions a special case was studied of complete scallops forming on the end cap of the airfoil although no complete scallops were present along the span of the airfoil. Since the tunnel conditions were the same for the span and end cap, this case shows that sweep angle (due to curvature on the end cap in this case) has a strong influence in the formation of scallops.

\section{Experimental Procedure}

\section{Icing Research Tunnel}

Figure 1 shows the Icing Research Tunnel. The IRT is a closed-loop refrigerated wind tunnel with a test section 1.8 meters ( 6 feet) high, 2.7 meters ( 9 feet) wide and 6.0 meters (20 feet) long. The total air temperature in the test section can be varied between $-30^{\circ} \mathrm{C}\left(-20^{\circ} \mathrm{F}\right)$ and $+1^{\circ} \mathrm{C}\left(+33^{\circ} \mathrm{F}\right)$ within $\pm 0.5^{\circ} \mathrm{C}\left( \pm 1^{\circ} \mathrm{F}\right)$. Velocities up to $160 \mathrm{~m} / \mathrm{s}$ (350 mph) can be obtained with a blockage of $5 \%$ in the test section. A spray system allows control of the liquid water content (LWC) between 0.2 to 3.0 grams per cubic meter. The spray nozzles provide droplet median volume diameters (MVD) from 15 to $40 \mu \mathrm{m}$.

\section{Model}

The model chosen for this study was a NACA 0012 Swept Wing Tip (figure 2). The airfoil is made of wood, with a 0.381 meter (15 inch) chord measured normal to the leading edge, and a 0.609 meter (24 inch) span. It is mounted in the tunnel on a stand that allows pivoting of the airfoil to sweep angles of $0^{\circ}, 15^{\circ}$, $30^{\circ}$, and $45^{\circ}$. The end of the airfoil is fitted with an end cap. For sweep angles of $30^{\circ}$ and $45^{\circ}$ a small extension was fitted at the base of the airfoil to improve the airflow. A heater was installed on the area where the measurements and collection of ice shapes were going to be performed. A grid was painted on the surface of the heater to allow identification of the flow direction on the photographic data and to serve as a distance scale in some pictures.

\section{Castings}

For each one of the NACA 0012 icing runs, a urethane casting was made of the ice shape. The castings provided data on initial formation, and helped identify the mechanisms of scallop growth. The castings also allowed measurement of scallop spacing and height.

In the discussion of the data, reference is made to individual castings by giving the sample number in parenthesis, but no figures are presented of each casting. To illustrate how the castings look in general, figure 3 shows the casting for the $45^{\circ}$ sweep angle base case.

\section{Icing Measurements}

For each run, a set of measurements was taken directly on the ice shape. The height of the ice accretion was measured with a ruler at the attachment line location, the extent of chordwise growth was measured, the direction of growth of the scallops tip was recorded, as well as the number of scallops present in a given distance along the span of the airfoil.

\section{Test Matrix for Icing Runs}

Table 1 lists the test matrix for the icing runs. A base case condition: $45^{\circ}$ sweep angle, $150 \mathrm{mph}, 25^{\circ} \mathrm{F}, 0.75$ $\mathrm{g} / \mathrm{m}^{3}$ LWC and $20 \mu \mathrm{m}$ MVD was chosen because complete scallops are formed. At this condition runs were made at ice accretion times of $0.5,1,2,3,4,5$, $6,7,8,9$, and 10 minutes to study the time history of scallop formation. Changing the sweep angle to $30^{\circ}$ and $15^{\circ}$, but maintaining the other parameters of the base conditions unchanged, runs were made for 2,5 , 8 , and 10 minutes to study the time history of scallop formation at those sweep angles and to compare to the $45^{\circ}$ sweep angle case. In addition starting from the base case, one parameter was changed at a time to study the velocity, temperature and LWC effects at sweep angles of $45^{\circ}, 30^{\circ}$, and $15^{\circ}$. 


\section{Test Procedure}

Before the start of each run, the leading edge of the airfoil was covered with a removable fabric shield held on to the airfoil by Velcro strips. The tunnel was brought to the target velocity and total temperature. The video systems were started and the tunnel spray system was started. When the tunnel conditions stabilized, the ice accretion was initiated by pulling off the fabric shield by hand to expose the airfoil to the icing cloud. During the run the tunnel parameters were recorded using the NASA-Lewis Escort data acquisition system. Once the target ice accretion time was reached, the tunnel was brought to idle and the video system was stopped. After entering the tunnel photographic data was taken with a $35 \mathrm{~mm}$ camera and with a digital camera following a predetermined sequence and location for the pictures. Then three cuts were made on the ice accretion to prepare the ice shape for removal. Following this, the icing measurements discussed above were taken directly on the ice accretion and general observations were recorded. The heater was activated and two samples of the ice shape were removed taking special care not to melt or damage the ice shape in the process. The removed ice shapes were taken to the casting area and bees' wax molds were made. The airfoil was cleaned, and the removable fabric shield was reinstalled before the next run.

\section{Experimental Observations on Scallop Formation}

To establish the time-history of the formation of the scallops, that is, how they form and grow with time, tests were run to obtain photographic data and ice shape castings. Both types of data are crucial and they complement each other. The photographic data provide close-up detail, while the casting data support the results from the photographic data, provide threedimensional information on the formation of the scallops, and allow direct measurement of scallop parameters. In addition, icing measurements and video data were obtained for each run.

\section{Base Case ( $45^{\circ}$ Sweep Angle)}

Figure 4 shows the ice accretion for the base case. Each large pointed ice structure is called a scallop. The NACA 0012 model is a swept-back type of airfoil, and the scallops point downward into the flow. Although individual scallops look different, there is a clear similarity between them, and a periodicity in their distribution along the airfoil. For each scallop the area around the attachment line is called the base of the scallop, while the pointed part is called the tip of the scallop. The separation between individual scallops is called the spacing. For the base case the spacing varies, some scallops are almost touching each other, while others are well separated. In a few cases, a scallop on one side of the airfoil is located exactly opposite to another on the other side, but in general a scallop on one side is aligned between two scallops on the other side. Figure 5 is a side view of the scallops of the base case, showing the glaze ice feather structure that forms the scallops, with the feathers at an angle with respect to the airfoil pointing into the direction of the flow.

The video data showed that in all cases the beginning of the ice accretion process was similar to what has been reported ${ }^{7}$ for the $2 \mathrm{D}$ case: the small supercooled incoming water droplets impinge on the surface of the airfoil and form droplets that are moved downstream by wind forces, then the drops stop moving and the ice accretion begins to form.

At an ice accretion time of 0.5 minutes (figure 6), there is a thin layer of ice covered with roughness elements, the average diameter of the roughness elements located around the attachment line area is of the order of 0.5 millimeters. The roughness elements cover all the ice, no empty areas can be seen. Away from the attachment line at a distance of about 6 millimeters, larger roughness elements can be observed.

At an ice accretion time of 1 minute (figure 7 ), the ice accretion is similar to the one at 0.5 minutes, but the roughness elements located around the attachment line area have now grown to an average diameter of 1 millimeter, and roughness elements located at a distance of about 6 millimeters from the attachment line are still larger than the other roughness elements and some of them show a tooth shape.

At an ice accretion time of 2 minutes (figure 8), all the roughness elements that covered the ice at 1 minute have now grown into glaze ice feathers. All the ice accretion is covered with the glaze ice feathers, along the attachment line area and away from it. The glaze ice feathers have a tooth shape, and therefore a preferred direction of growth (the direction along which a feather is growing faster laterally, that is, the direction of the larger axis for the tooth shape of the top of the feather). The feathers are also inclined into the flow. The preferred direction of growth of the 
glaze ice feathers in the attachment line region is perpendicular to the flow along the attachment line, away from the attachment line is at an increasingly clockwise angle. The preferred direction of growth of the feathers is in a direction perpendicular to the streamlines direction. Another important feature is the joining of glaze ice feathers along the preferred direction of growth to form ridges. Several of these ridges can be seen starting to form away from the attachment line area. The casting data (061896.04;1) shows that all the surface of the ice accretion is covered with feathers with a preferred direction of growth, forming ridges by joining along that preferred direction of growth. Some of the ridges are short, made of only two feathers joining along the direction of preferred growth, others are made of three or more feathers. Some of the ridges begin nearly at the attachment line, others start at some distance from it. The average thickness of the ice with the feathers was 3.3 millimeters. The separation between ridges was 2.6 millimeters. The average total extent of the ice accretion around the leading edge was 26.4 millimeters.

At an ice accretion time of 3 minutes (figure 9) the glaze ice feathers covering all the ice accretion have grown in height. Away from the attachment line, nonuniformly spaced ice formations pointing downwards into the flow can be observed, these formations are the tips of the incipient scallops. The characteristic spacing between the scallops is starting to appear. Close-up observation of the ice accretion (figure 10) shows the glaze ice feathers forming the ice accretion, their growth in a preferred direction and their joining to form incipient scallops. The tendency of the glaze feathers to grow in a preferred direction makes them join other feathers in that direction forming ridges, and makes them tend not to join feathers that are not located along that preferred direction, this creates and enhances the spacing between the ridges. The growth in the preferred direction by the feathers that are located on the ridge further away from the attachment line, leads to the downward pointing ice formation that characterizes the tip of the scallops, and also enhances the spacing between the scallops. The casting data $(061896.05 ; 1)$ shows that the ridges are now larger, with the spacing between them well defined, beginning to form scallop tips. The average thickness of the ice was 5.3 millimeters, the average spacing 2.62 scallops per centimeter.

At an ice accretion time of 4 minutes (figure 11) the incipient scallops are more defined and their downward pointing shape is more marked. The spacing between the scallops is more accentuated and it varies. The scallops are not exactly alike but they resemble each other. Figure 12 is a close-up view of the ice accretion, the large ice structure in the center-left side of this figure is a scallop pointing towards the left. The joining of the feathers to form the scallops can be seen. This joining is the result of feathers touching each other along the preferred direction of growth. Along the attachment line the feathers join not only with other feathers along the preferred direction of growth, but also with those feathers located around them. This joining is sometimes done by touching of two feathers, at other times it seems that water helped by surface tension builds a bridge between feathers, in other instances water fills the close space between two feathers. This joining, bridging and filling forms solid ice pieces that can be seen in the attachment line area. The casting data $(061896.06 ; 4)$ shows how the ridges have grown and are beginning to form better defined scallop tips, the spacing between the scallop tips can be observed. Measured on the casting the average height was 8.4 millimeters, the average spacing 1.71 scallops per centimeter.

For an ice accretion time of 5 minutes (figure 13) more areas of solid ice are observed along the attachment line, resulting from the joining, bridging and filling between feathers. Away from the attachment line the scallops look more developed, the spacing between them is more marked. The individual scallops are different from each other, but they share some similarity in their shape. Two zones can be defined on the ice accretion: a zone along the attachment line with areas of solid ice, and a zone away from the attachment line where the tip of the scallops can be seen. Away from stagnation the scallops tips are made of feathers joined with each other along the preferred direction of growth, and in some cases they are also made of feathers of a scallop tip joining the feathers of another scallop tip at their tops. This is difficult to see because what is shown on the picture is the top of the joined feathers that make the scallops. This point is illustrated by figure 14, which shows the ice accretion from the side, away from stagnation. On the center of the picture, between the two stripes, two feathers are joined at the top, and the solid ice piece at the top can be seen. The top of the feathers is what we were observing away from stagnation on figure 13. The casting data $(061996.02 ; 1)$ shows that the average height was 10.0 millimeters, the average spacing 1.73 scallops per centimeter. 
At an ice accretion time of 7 minutes (figure 15) more areas of solid ice can be seen along the attachment line area, with some parts looking more like typical clear glaze ice covered with roughness elements, while others have ice that is less clear, of a more dull color. Some solid ice areas are also appearing on the tip of the scallops, due to the joining of the scallop tips at their tops. This fusion of the tops of two scallop tips creates a thicker new one. By this mechanism the scallop tips grow in size, enhance the spacing between them, and is the reason why the average spacing between the scallops (number of scallops per unit distance along the attachment line) decreases with ice accretion time. The tips of the scallops point downwards into the flow. Considering the length of a scallop as the distance from the attachment line to the tip, we can see this length varies for each scallop. Spacing between individual scallops also varies. This can be expected since the tips of scallops eventually merge together, and for this to happen some of the tops of the scallop feathers that form the tips at a given time must be very close to each other. The length of the separation between scallops varies, sometimes ending near the attachment line area, in others cases very short. The casting data (061996.04;1 and 061996.04;2) allows to identify the mechanism of growth of the scallop tips. The feathers that form a scallop tip join the top of the feathers of another scallop tip to form a larger one. The joining of the feathers at their tops is what forms the areas of solid ice observed on the scallop tips. The casting data also shows the increase in overall size of the ice shape as the ice accretion time increases, due to the growth of the scallops in the preferred direction normal to the streamlines (the tip length increases in average); the increase in height of the feathers; and the increase due to tips of the scallops merging together, when their feathers merge at their top. The castings show that at this ice accretion time the average height was 13.5 millimeters, the average spacing 1.58 scallops per centimeter.

At an ice accretion time of 8 minutes (figure 16) the areas of solid ice are more numerous now on the ice accretion. Some of the solid ice looks clear, with roughness elements, while other parts look dull. Near the attachment line there are areas of solid ice. The size of the roughness elements is of the order of 1 millimeter or less. The individual scallops now look larger due to the merging of individual scallops at the top of their feathers to form a new one. On the casting $(061996.05 ; 1)$ the joining of the top of the feathers of the individual scallops that joined to form the new one can be clearly observed. The scallops have their characteristic downward inclination into the flow, and their length seems more uniform. The spacing between individual scallops still varies but seems more marked. The average height was 16.9 millimeters, the average spacing 1.21 scallops per centimeter.

At an ice accretion time of 10 minutes (figure 17) the scallops look larger and well defined, they show the typical characteristics associated with them: well defined tips inclined into the flow, marked spacing, most of the top surface made of solid ice. The increase of the scallop length (distance from the attachment line to the tip of the scallop), and the increase in height of the feathers that make up the scallops, results in larger scallop spacing as the ice accretion time is increased. The length of the spacing gap varies, in most of the cases going to the attachment line area, but in some cases is shorter. The areas of clear ice show roughness elements on their surface. Figure 18 shows a scallop that was removed from the ice accretion and placed on its side. The concave area is the part that was attached to the ice accretion on the airfoil. On the side of the scallop, the feathers that have joined together to form the whole scallop can be seen. The feathers are made of clear ice, this is especially apparent on the feathers at the extreme sides of the scallop, they are quite transparent. The casting data (061996.07;1 and $061996.07 ; 2$ ) show the feathers that form the scallops and their inclination into the flow, the joining of scallop tips at the top of the feathers, and the areas of solid ice that they form. At this ice accretion time the average height was 21.5 millimeters, the average spacing 0.92 scallops per centimeter.

\section{$30^{\circ}$ Sweep Angle}

For the $30^{\circ}$ sweep angle base case, photographic and casting data were obtained for ice accretion times of $2,5,8$, and 10 minutes. The only change with respect to the base case was in the sweep angle, the other conditions were the same.

At an ice accretion time of 2 minutes (figure 19) two different zones were identified, each with their own characteristics. The attachment line zone starts at the attachment line and extends 6 millimeters on each side (measurement taken from the photographic data), and is covered with roughness elements of the order of 1.5 millimeters in diameter or less (figure 20). The roughness elements cover all the ice of this zone, no areas were observed without them. Elements of 
different diameters seem mixed together, but there are larger elements near the end of the zone. The glaze ice feathers zone begins at either end of the attachment line zone and extends for about 10 millimeters. The smaller feathers located after the glaze ice feathers zone do not play a major part in the formation of the main ice accretion and for this reason are not included in the definition of the glaze ice feathers zone. The casting data $(062096.02 ; 1)$ shows the two distinct zones confirming the photographic observations. The average distance from the attachment line proper to the end of the attachment line zone was measured at 6 millimeters. The average value of the ice thickness was measured at 2.5 millimeters. The height of the feathers in the glaze ice feathers zone is of the order of 2 millimeters or less. The main information that the casting provides is that the feathers show a preferred direction of growth and that they are joining with other feathers along this direction to form ridges. The ridges nearest the beginning of the glaze ice feathers zone point in a direction that makes a large angle with respect to the attachment line direction. For the ridges located further from the beginning of the zone, their direction tends to make a smaller angle with respect to the attachment line direction, in other words, the further the ridge from the attachment line, the less turning with respect to the attachment line direction. It appears that the preferred direction of growth of the feathers, namely the direction of the ridges, tends to be normal to the streamlines, as was observed in the $45^{\circ}$ sweep angle cases. The overall shape of the ice accretion can be described as curved from the attachment line to the beginning of the glaze ice feathers zone, where the ice is thicker due to the feathers.

At an ice accretion time of 5 minutes (figure 21) the attachment line zone and the glaze ice feathers zone can be observed. The glaze ice feathers zone begins at the same distance from the attachment line $(6$ millimeters) as at an ice accretion time of 2 minutes, which indicates that roughness elements at a distance less that 6 millimeters do not develop into glaze ice feathers. The glaze ice feathers in the glaze ice feathers zone have grown in height compared to the ones at an ice accretion of 2 minutes. The feathers show a preferred direction of growth and the formation of ridges (figure 22) similar to what was observed for a sweep angle of $45^{\circ}$. The glaze ice feathers and/or the ridges that they form look like scallop tips (figure 21). The ice with the small roughness elements that constitutes the attachment line zone has grown thicker faster that the glaze feathers and now the height of the whole ice accretion is basically the same. The separation between the two zones looks well delineated in the pictures that are not close-up views of the ice accretion (figure 21), but when close-up pictures are analyzed it can be seen that the separation between the two zones is not well delineated, and that the ice of the attachment line zone with the small roughness elements has covered part of the glaze ice feathers zone (figure 23), covering part of feathers and in some cases whole feathers. All the attachment line zone ice is covered with roughness elements with a diameter of the order of 1.6 millimeters or less. The roughness elements cover all the ice of the attachment line zone, no part of the ice is observed without them.

The casting data $(062096.02 ; 2)$ shows that the overall shape of the ice accretion is curved trying to follow the contour of the airfoil, the ice at the attachment line zone has now nearly the same thickness as the ice at the glaze ice feathers zone. The beginning of the glaze ice feathers zone cannot be observed, what can be observed is the ice of the attachment line zone extending up to an area where glaze ice feathers can be seen, in one side of the ice accretion the ice of the attachment line zone virtually covers the tops of all the feathers, but from the side the feathers can be seen clearly. At the other end of the glaze ice feathers zone, the ice of the attachment line zone does not cover all the feathers and the feathers form ice formations that can best described as incipient tips of scallops. The feathers that form the incipient tips of scallops are aligned in a preferred direction of growth (namely the direction of the tip), this direction varies from one incipient tip to other, but in general it seems to oscillate between $30^{\circ}$ to $40^{\circ}$ with respect to the attachment line direction. The feathers forming the incipient tips are clearly visible particularly from the side.

At an ice accretion time of 8 minutes (figure 24) the two zones can be seen. The attachment line zone extends about 6 millimeters at each side from the attachment line (measurement taken from the photographic data), then the glaze ice feathers zone begins and extends for about 11 millimeters. The ice of the attachment line zone covers nearly all the feathers of the glaze ice feathers zone (figure 25), only the feathers at the end of the zone are not totally covered. The clarity of the attachment line zone ice allows to see all of the glaze ice feathers zone, even if part is covered by its ice (figure 25). The feathers of the glaze ice feather zone have a preferred direction of growth and form ice structures that are identical to 
tips of scallops. The spacing between those tips can be observed. The ice of the attachment line zone is covered with roughness elements of the order of 1.5 millimeters or less in diameter, large and small elements are mixed together, no discernible pattern can be observed.

The casting data $(062096.03 ; 2)$ emphasizes the significant change in the ice accretion between 5 minutes and 8 minutes. The ice accretion is no longer curved. The average thickness at the attachment line zone is $11.5 \mathrm{~mm}$. The average thickness or height of the feathers was measured at $15.4 \mathrm{~mm}$. On the front part of the ice accretion, looking from a normal view, the ice between the attachment line proper and the beginning of the glaze ice feathers zone is slightly thicker than the ice of the glaze ice feathers zone. There is a step in the ice height where the glaze ice feathers zone begins which allows to distinguish the between two zones. That this step is the beginning of the glaze ice feathers zone is confirmed by the photographic data and by the actual casting because of the way the ice looks after the step, identical to scallop tips. The average distance from the attachment line proper to the step is $5.8 \mathrm{~mm}$. The ice of the attachment line zone looks more bumpy and uneven. The glaze ice feathers zone looks covered by the ice of the attachment line zone but the scallop tips that the feathers form are well defined. The spacing between the scallop tips is well marked, the tips point downward into the flow. Some of the roughness elements of the attachment line zone ice covering the glaze ice feathers zone can be observed. Observation of the casting from the side allows a view of the feathers at the end of the attachment line zone, the feathers that form the end part of the scallop tips. The base and top of the feathers can be seen clearly, their tooth shape due to a preferred direction of growth. The feathers sometimes stand alone, sometimes join other feathers to form the end of structures that are identical to scallops tips. The ice of the attachment line zone can be observed spilling over the top of the feathers or filling the spacing between them.

At an ice accretion time of 10 minutes (figure 26) the two zones can be seen, the attachment line zone extends about 6 millimeters at either side of the attachment line (measurement taken from the photographic data), and then the glaze ice feathers zone begins. The glaze ice feathers zone extends 16 millimeters, it has increased compared to previous ice accretion times because of the growth of the feathers. The attachment line zone is covered with roughness elements, an estimate of an upper bound on their diameter, cannot be obtained from the data. The ice of the attachment line zone covers nearly all the feathers of the glaze ice feathers zone. We can see all the glaze ice feathers zone because of the transparency of the attachment line zone ice. The ice of the attachment line zone covers the glaze ice feathers, and covers part or in some cases all the side of those feathers (figure 27). The role of the feathers in the formation of the ice accretion is starting to cease. The feathers of the glaze ice feathers zone (figure 26) form ice structures that are identical to the tips of scallops that were observed at $45^{\circ}$ sweep angle, and have well marked spacing.

The casting data $(062096.04 ; 1)$ shows that the ice accretion is larger than for the 8 minutes case, but the overall shape remains similar. The ice of the glaze ice feathers zone (feathers and attachment line zone ice covering them) is nearly level with the ice covering the attachment line zone proper. The average thickness at the attachment line zone is $15.2 \mathrm{~mm}$, the thickness or height of the feathers was measured at $20.3 \mathrm{~mm}$. The two zones can be distinguished because there is a "step" in the ice shape at the point where the glaze ice feathers zone begins. Although the glaze ice feathers zone is covered with the ice of the attachment line zone, the step in the ice indicates the beginning of the glaze ice feathers zone as is confirmed by the photographic data. The average distance from the attachment line proper to the step is 5.7 millimeters, which agrees well with the beginning of the glaze ice feathers zone observed in the photographic data, and it is nearly identical with the value measured for the 8 minutes case. The ice of the attachment line (the attachment line proper, and the attachment line zone ice covering the glaze ice feathers zone) is fairly bumpy, with the bumps covered by roughness elements. The ice of the attachment line zone is covering all the glaze ice feathers zone. Despite being covered by the ice of the attachment line zone, the feathers in the glaze ice feathers zone form structures that are identical to the tips of scallops pointing downward into the flow, and the spacing between those tips can be seen. Observing the ice accretion from the side, the feathers at the end of the glaze ice shape zone can be seen clearly, their tooth shape resulting from a preferred direction of growth, and they are aligned along that preferred direction of growth. It can be observed how the feathers form structures similar to the tip of scallops, and how the feathers join at their tops to form a tip, an identical mechanism to what was observed when discussing the data for a $45^{\circ}$ sweep 
angle. The ice of the attachment line zone is spilling over the top of the feathers, in some cases it is beginning to cover the side of feathers, and it is also filling the spacing between the tip of scallops formed by the feathers.

\section{$15^{\circ}$ Sweep Angle}

For the $15^{\circ}$ sweep angle base case, photographic and casting data were obtained for ice accretion times of $2,5,8$, and 11.6 minutes. The only change with respect to the base case was in the sweep angle, the other conditions were kept the same.

The ice accretion at 2 minutes (figure 28) presents two well-defined zones similar to the ones observed for a sweep angle of $30^{\circ}$. The attachment line zone that starts at the attachment line and extends 10 millimeters on each side (measurement taken from the photographic data), and is covered with roughness elements whose diameters are of the order of 1.6 millimeters or less, with elements of different diameters mixed together. All the ice is covered by these elements which lie next to each other, no area is seen without them. At the ends of the attachment line zone the glaze ice feathers zone begins, it extends 6.5 millimeters, only the feathers in that area are large in size and seem to be the ones that play a role in the formation of the ice accretion. At the end of this zone there are small feathers that play no role in the formation of the main ice accretion. The largest feathers in the glaze ice feathers zone are of the order of 2.5 millimeters in height. The height of the ice on the attachment line zone is smaller than the height of the feathers.

The casting data $(062096.05 ; 1)$ shows the two zones observed on the photographic data. The attachment line zone is covered with roughness elements and the average distance from the attachment line proper to the end of the zone is 9.3 millimeters. The roughness elements can be observed clearly, and their diameter is of the order of 1.5 millimeter for the largest ones, with the majority being 1 millimeter or less. The thickness of the ice has an average value of 2.7 millimeters. This thickness includes the substrate of ice where the feathers grew, so it indicates that the feathers height is of the order of 3 millimeters or less, this was confirmed by direct measurement of the feathers only, on the casting. The main information that the casting provides is that the feathers show a preferred direction of growth and that they are joining with other feathers along this direction to form ridges. The ridges nearest the beginning of the glaze ice feathers zone point in a direction that makes an angle close to $0^{\circ}$ with respect to the attachment line direction. The preferred direction of the feathers and the ridges that they form in that direction have less turning with respect to the attachment line direction than for the $30^{\circ}$ case. This should be expected because the location of the first feathers in the glaze ice feathers zone for the $15^{\circ}$ case is further away from the attachment line proper than for the $30^{\circ}$ sweep angle case, and we observed that the preferred direction of growth tends to be normal to the streamlines, and the further you are from the attachment line proper the more the turning of the streamlines with respect to the attachment line direction and the less the turning of the feathers preferred direction of growth with respect to the attachment line direction (it should also be kept in mind that at a given distance from the attachment line the streamlines for a $15^{\circ}$ sweep angle are turning faster than the streamlines for $30^{\circ}$ ). The overall shape of the ice accretion can be described as curved from the attachment line to the beginning of the glaze ice feathers zone, where the ice is thicker due to the feathers.

At an ice accretion time of 5 minutes (figure 29) the two zones are present but the ice of the attachment line zone covers nearly all the feathers of the glaze ice feathers zone (figure 30). The glaze ice feathers zone can be seen despite being covered by the ice of the attachment line zone because the transparency of the ice. The ice of the attachment line zone is covered with roughness elements of the order of 1.5 millimeters in diameter or less, large and small elements mixed together, covering all the ice, without leaving any empty areas. The shape of the ice accretion at the attachment line zone is curved, while the shape of the glaze ice feathers can be best described as a short, uneven, inclined ramp that begins at the end of the attachment line zone as a change in the slope of the ice accretion. The thickness at the attachment line location is 6.4 millimeters, and at the end of the glaze ice feathers zone the thickness is $\mathbf{8 . 3}$ millimeters, showing that the ice of the glaze ice feathers zone has grown faster. The attachment line zone extends 10.5 millimeters at each side of the attachment line proper (measurement taken from the photographic data). The ice of the attachment line zone is covering all of the glaze ice feathers zone, it spills over the top of the feathers at the end of the zone, and it is beginning to cover their side. The feathers have a tooth shape because of their growth in a preferred direction, which is nearly aligned with the attachment line direction. The 
feathers do not form structures that resemble tip of scallops because they are covered by the ice of the attachment line zone and the preferred direction of growth of the feathers is in the attachment line direction, which make the ridges formed by the joining of the feathers along the preferred direction of growth align with the attachment line direction, which does not favor the formation of structures similar to scallops tips.

At an ice accretion of 8 minutes (figure 31 ) the two zones can be seen but the glaze ice feathers zone is all covered with the ice from the attachment line zone. This ice not only covers the feathers but also spills over at the ends, and is covering the side of the feathers at the end of the glaze ice feathers zone. The only reason that the glaze ice feathers zone can be seen is because of the transparency of the ice. At this point the feathers are so totally covered with the ice of the attachment line zone that their role in the formation of the main ice accretion has stopped. The ice of the attachment line zone is covered with roughness elements of the order of 1.5 millimeters or less, large and small elements mixed together, covering all the ice, without leaving any uncovered areas. The casting data $(062096.07 ; 2)$ shows an increase in the size of the ice accretion keeping almost but not quite the same basic shape that was observed at 5 minutes. The shape of the ice accretion at the attachment line zone is curved. The shape of the glaze ice feathers zone can best be described as a short, uneven, inclined ramp that begins at the end of the attachment line zone as a change in the slope of the ice accretion. The extent of the glaze ice feathers zone is now $\mathbf{1 0 . 6}$ millimeters. The thickness at the attachment line location is 10.2 millimeters, at the end of the glaze ice feathers zone the thickness is 13.7 millimeters. The ice of the attachment line zone is covered with roughness elements, in addition some large bumps can be seen in the range of 2 to 4 millimeters in size, but it is not possible to distinguish if these are roughness elements in themselves or just large bumps covered by roughness elements. The attachment line zone extends 10.5 millimeters at each side of the attachment line proper.

At an ice accretion time of 11.6 minutes (figure 32) the two zones are still visible. The extent of the glaze ice feathers zone is 19 millimeters. The roughness elements that cover the ice of the attachment line zone are of the order of $\mathbf{1 . 6}$ millimeters or less, large and small elements mixed together, covering all the ice, without leaving uncovered areas. On the side of the ice accretion, the ice of the attachment line zone that covers the side of the feathers appears covered with ice formations that are much larger than the typical roughness elements covering the ice of the attachment line zone (figure 33). The casting data $(062096.08 ; 1)$ shows that the attachment line zone extends 10.5 millimeters at each side of the attachment line proper. The extent of the glaze ice feathers zone it is now 12.6 millimeters. The ice thickness at the attachment line location is 13.6 millimeters, at the end of the glaze ice feathers zone the thickness is 18.7 millimeters. The ice of the attachment line zone is covered with roughness elements, in addition some large bumps are observed, they can be as large as 5 millimeters in diameter. These bumps are covered by typical roughness elements observed in the attachment line ice. The ice of the attachment line zone completely covers the glaze ice feathers zone.

\section{Special Case for $15^{\circ}$ Sweep Angle}

For the $15^{\circ}$ sweep angle cases it was observed that along the span of the airfoil not complete scallops occur, but on the end cap of the airfoil large and complete scallops occur. The scallops on the end cap were studied for ice accretion times of 5, 8, and 11.6 minutes. At an ice accretion time of 5 minutes (figure 34) the scallops are not formed yet, but large glaze ice feathers with a preferred direction of growth and the resulting tooth shape have joined along the preferred direction of growth to form ridges (figure 35 ). In the area next to where the span of the airfoil ends and the end cap begins some of the ridges are beginning to join with others, further downstream the ridges look more isolated. These are the same mechanisms of formation observed for scallop formation on a $45^{\circ}$ sweep angle. At an ice accretion of 8 minutes (figure 36) the ice accretion on the end cap is beginning to show more developed scallops in the part of the ice accretion where the span of the airfoil ends and the end cap begins, above this area some ridges can be observed. On figure 37 one of these ridges (viewed directly from above) is shown to illustrate the disparity between the growth of the feathers in the preferred direction (normal to the streamlines), versus growth in the direction of the flow. The length of the ridge is $\mathbf{2 5 . 4}$ millimeters, and the largest thickness measured on the ridge is 4.4 millimeters. Some roughness elements can be seen on the top of the feathers forming the ridge. At an ice accretion time of 11.6 minutes the scallops on the end cap are already well defined (figure 38). Along the span the ice accretion shows no scallops, but once the span ends and the end cap begins the change in 
the nature of the ice accretion is immediate and dramatic (figure 39). Since the tunnel conditions are the same for the ice accretion along the span and along the end cap, the special case shows the strong effect of the sweep angle on the nature of the ice accretion and specifically on the formation of the scallops.

\section{Results and Discussion}

\section{Summary of Physical Mechanisms}

Scallop formation is governed by local effects on roughness elements. Roughness elements formed at the beginning of the ice accretion process develop into glaze ice feathers when they reach a given height, and they are located beyond a given distance from the attachment line. This distance depends on sweep angle and tunnel conditions, and defines the boundary between the attachment line zone, where roughness elements do not become feathers, and the glaze ice feathers zone.

For formation of complete scallops all the roughness elements of the ice accretion must develop into feathers (only the glaze ice feathers zone is present). When this occurs the feathers exhibit an inclination into the flow, and a preferred direction of growth perpendicular to the streamlines. The preferred direction is normal to the attachment line for feathers located on the attachment line, and the angle decreases as the distance from the attachment line increases. The feathers join along the preferred direction of growth to form ridges, with incipient scallop tips formed by the feathers at the end of each ridge. As the ridges grow they form scallop tips. As the scallop tips grow in height and along the preferred direction, they merge with adjacent scallop tips by joining at the top of the feathers that form each scallop tip. This mechanism is responsible for the growth of the scallop tips, their increase in size, and the enhancing of the spacing between scallops. Along the attachment line area the feathers tend to join other feathers around them by touching, bridging and filling, in this way they form areas of solid ice that are also covered with roughness elements. As the scallops tips grow by joining at their tops, the top surface tend to fill in with water and areas of solid ice also can be observed with roughness elements present.

When not all the roughness elements grow to become feathers but only the ones located beyond a given distance from the attachment line, incomplete scallops develop. In this case the two zones will be present and depending on the tunnel conditions one will prevail over the other. For some conditions, as the ice accretion time increase, the ice of the attachment line zone will start covering the glaze ice feathers, if the ice accretion is continued eventually all the feathers are covered and they cease to play a role in the formation of the ice accretion. Before the feathers are covered with ice of the attachment line zone they may form scallops tips or not, depending on the angle that the preferred direction of growth of the feathers at the end of the zone make with the attachment line direction, which in turn depend on the distance from the attachment line that those feathers are located. For other conditions, the glaze ice feathers zone may prevail over the attachment line zone and the feathers may grow fast and form large scallops tips, and in some cases nearly complete scallops (a case will be discussed in the section on the velocity effects). In all cases, the distance from the attachment line beyond which the roughness elements become glaze ice feathers is a critical factor in the kind of ice accretion that will form.

\section{Velocity Effect}

For a $45^{\circ}$ sweep angle, icing runs were carried out at velocities of $250 \mathrm{mph}$ and $100 \mathrm{mph}$ while keeping the other parameters of the base case unchanged. For $250 \mathrm{mph}$ (figure 40) the scallops are better defined than for the base case, with each individual scallop extending to the attachment line where it joins the scallop from the other side of the airfoil to form a complete solid piece. The spacing between scallops is extremely well marked, with the gap extending to the attachment line. For $100 \mathrm{mph}$ (figure 41) scallops form but they are less defined, the scallop tips are beginning to form, and the area around the attachment line is made up of feathers nearly touching each other. The casting data $(062196.03 ; 1)$ shows that the basic mechanisms of scallop growth are still present.

For the $30^{\circ}$ sweep angle, icing runs were carried out for velocities of $200 \mathrm{mph}$ and $250 \mathrm{mph}$. At $200 \mathrm{mph}$ (figure 42) the ice accretion is made of large scallops tips in the glaze ice feathers zone that start at a distance of 2 millimeters from the attachment line proper. The large scallop tips dominate the ice accretion, the glaze ice feathers zone prevails over the attachment line zone. The increase in velocity from $150 \mathrm{mph}$ to $200 \mathrm{mph}$ moves the distance at which the roughness elements develop into glaze ice feathers from 6 to 2 millimeters. At a speed of 250 mph (figure 43) the ice accretion is made of complete scallops. 
For the $15^{\circ}$ sweep angle icing runs were carried out at velocities of $200 \mathrm{mph}$ and $250 \mathrm{mph}$. At $200 \mathrm{mph}$ (figure 44) the ice shape shows no scallops but the attachment line zone and the glaze ice feathers zone are still present with the ice of the attachment line zone covering all the glaze ice feathers zone. The distance from the attachment line proper to the beginning of the glaze ice feathers zone is 6.8 millimeters. The casting data $(062196.06 ; 3)$ shows that the attachment line ice covering the feathers grows faster than the attachment line zone ice and is beginning to form horns. At $250 \mathrm{mph}$ (figure 45) the attachment line zone and the glaze ice feathers zone can be observed. The distance from the attachment line proper to the beginning of the glaze ice feathers zone is 4 millimeters. The ice of the attachment line zone covering the glaze ice feathers zone has grown faster than the ice of the attachment line zone proper and is forming horns inclined at a steeper angle than for the $\mathbf{2 0 0} \mathrm{mph}$ case.

\section{Temperature Effect}

For a $45^{\circ}$ sweep angle, runs were carried out at a temperature of $20{ }^{\circ} \mathrm{F}$ (other base conditions unchanged) for ice accretion times of $2,5,8$, and 10 minutes. At an ice accretion time of 2 minutes (figure 46) there is an area around the attachment line where the feathers are closely packed and they fuse into a solid ice piece, the total width of this area is 8 millimeters. Away from the attachment line individual regular feathers are observed. At an ice accretion time of 10 minutes, the area around the attachment line remains a solid ice piece (figure 47) with a feather type formation on the surface. The feathers away from stagnation form incipient scallop tips. Tests were run at a temperature of $10^{\circ} \mathrm{F}$ at ice accretion times of 2 and 5 minutes. In both cases the ice accretion follows the same pattern as for the $20{ }^{\circ} \mathrm{F}$ case.

For $30^{\circ}$ and $15^{\circ}$ sweep angles, runs were carried out at a temperature of $29^{\circ} \mathrm{F}$ at an ice accretion time of 10 minutes with the other parameters maintained the same as the base case. For the $30^{\circ}$ sweep angle, the temperature change has a strong effect on the ice shape (figure 48 ). The casting data $(070396.02 ; 1)$ shows that the ice shape no longer resembles the one at $25^{\circ} \mathrm{F}$, the ice shape has a central thicker part with a level front surface of uneven ice covered with roughness elements. At the sides of the central part are large ice lumps, with additional ice lumps further away from the center. For the $15^{\circ}$ sweep angle (figure 49) the ice accretion no longer resembles the $25^{\circ} \mathrm{F}$ case. The casting data $(070396.06 ; 1)$ shows that the ice shape is similar in all the main features to the ice shape for the $30^{\circ}$ sweep angle at $29^{\circ} \mathrm{F}$.

\section{LWC Effect}

For a $30^{\circ}$ sweep angle, runs were carried at LWCs of 0.5 and $1.25 \mathrm{~g} / \mathrm{m}^{3}$ (other parameters of base case unchanged). The change in LWC has a strong effect on the ice shape. At a LWC of $0.5 \mathrm{~g} / \mathrm{m}^{3}$ (figure 50) the attachment line zone and the glaze ice feathers zone can be observed but there is solid ice around the attachment line zone with rod-like structures along it. The glaze ice feathers zone shows some scallop tips. At a LWC of $1.25 \mathrm{~g} / \mathrm{m}^{3}$ (figure 51) the ice shape is similar to the ice shape obtained for the case where the temperatures were increased to $29^{\circ} \mathrm{F}$, with the ice shape completely dominated by the ice of the attachment line zone.

For a $15^{\circ}$ sweep angle, runs were done at LWCs of 0.5 and $1.25 \mathrm{~g} / \mathrm{m}^{3}$. At a LWC of $0.5 \mathrm{~g} / \mathrm{m}^{3}$ the ice accretion (figure 52) is smaller and of a different shape but there is still some similarity to the $0.75 \mathrm{~g} / \mathrm{m}^{3}$ case. The attachment line zone and the glaze ice feathers zone can be observed. The attachment line ice is covered with roughness elements of 1.6 millimeters in diameter or less. The ice of the attachment line zone covers all the glaze ice feathers zone. The distance from the attachment line proper to the beginning of the glaze ice feathers zone is 6.3 millimeters, which is smaller than the $\mathbf{1 0 . 1}$ millimeters measured for the $0.75 \mathrm{~g} / \mathrm{m}^{3}$ case. At a LWC of 1.25 $\mathrm{g} / \mathrm{m}^{3}$ (figure 53, and casting 070296.04;1) the ice shape is radically different, showing a strong similarity to the cases for a temperature of $29^{\circ} \mathrm{F}$ and to the $30^{\circ}$ sweep angle case for the same LWC.

Increasing the temperature to $29^{\circ} \mathrm{F}$ and increasing the LWC to $1.25 \mathrm{~g} / \mathrm{m}^{3}$ has the same effect on the ice shape for the $30^{\circ}$ and $15^{\circ}$ sweep angle cases.

\section{Ice Accretion Data}

Scallop height was measured directly on the ice shape at the attachment line location. The height was also measured on each casting at different locations and an average value was calculated. On figure 54 scallop height in centimeters is plotted against ice accretion time in minutes for the $45^{\circ}$ sweep angle at the base case conditions. The scallop height increases linearly with ice accretion time, which indicates that the rate of growth of the feathers that 
form the scallops remains constant. From the graph, the rate of growth is measured at $0.21 \mathrm{~cm} /$ minute.

The main mechanism by which scallop tips grow is by the joining of the feathers of two scallop tips at their tops. Because of this mechanism the spacing between individual scallops varies, for scallop tips almost joining at their tops the spacing is very small, but for other scallops the spacing may be larger. For this reason the scallop spacing measured as the number of scallops in a given distance along the span is an average measurement. Figure 55 is a plot of scallop spacing measured in number of scallops per centimeter, against ice accretion time measured in minutes for the $45^{\circ}$ sweep angle at the base case conditions. At 1 minute the scallop spacing is large and then decreases rapidly, after the first two minutes the decrease is more gradual, nearly linear.

Table 2 lists the values of the distance from the attachment line to the point beyond where the roughness elements develop into glaze ice feathers for the cases where it could be measured either from the photographic data or from the casting data. For the cases where complete scallops were observed the value of distance is zero.

For the icing cases run, the range of values for the Reynolds number based on the 2D chord of the airfoil (0.381meters for the NACA 0012) were $1.4 \times 10^{6}$ to $3.5 \times 10^{7}$.

\section{Growth of Roughness Elements into Glaze lce Feathers In Scallop Formation}

The photographic and casting data show that for a given sweep angle and tunnel conditions only the roughness elements beyond a given distance from the attachment line grow into glaze ice feathers with a preferred direction of growth. This distance is critical since it determines if complete scallops, incomplete scallops or no scallops are present. Since the distance is repeatable and fairly constant along the span of the airfoil, it suggests that after the roughness elements reach a certain size, a physical mechanism or a combination of physical mechanisms is causing some heat enhancement that triggers the roughness elements beyond a given distance from the attachment line to grow into small feathers to a height at which the flow field and the heat transfer on the element protruding into the flow keep the feather growing in height and with a preferred direction. It is not known if the mechanism or mechanisms initiates the growth in the preferred direction or they only triggers the roughness elements to grow into glaze ice feathers. The unknown physical mechanisms appear to act only in the beginning of the ice accretion process, depend on tunnel conditions, and show a very strong dependence on the sweep angle as the special case for the $15^{\circ}$ sweep angle showed.

The strong dependence of scallop formation on sweep angle, suggest boundary layer instabilities as possible candidates for one of the mechanisms.

Three instabilities may be present in the laminar boundary layer on a NACA 0012 airfoil shape swept wing $^{8,9,10,11}$ : attachment line, streamwise, and crossflow instabilities. The instabilities may exist independently or simultaneously. The attachment line instability won't lead to transition if the attachment line Reynolds number ${ }^{12} R$ defined as

$$
R=\left[\frac{\left(V_{\infty} \cdot \sin \Lambda\right)^{2}}{\left.v_{e} \cdot \frac{d U_{e}}{d x}\right|_{x=0} ^{1 / 2}}\right]^{1 / 2}
$$

is less than 250. To calculate $R$, the chordwise velocity gradient at the attachment line was obtained using LEWICE 2D and also using the cylinder approximation:

$$
\left.\frac{d U e}{d x}\right|_{x=0}=\frac{2 \cdot V_{\infty} \cdot \sin \Lambda}{r}
$$

where $r$ is the leading edge radius of the airfoil. The value of the attachment line Reynolds for the conditions tested in the tunnel was always below 180 .

The streamwise instability is made of streamwise traveling waves, similar to the T-S waves in twodimensional flows. Near the leading edge the negative pressure gradient for the NACA 0012 swept wing damps out the streamwise turbulence but it creates a cross flow velocity that favors the crossflow instability. The crossflow instability appears in regions of strong pressure gradient on swept wings. The wing sweep and the pressure gradient curve the streamlines in the leading edge region, and in the boundary layer the presence of the wall lowers the momentum of the fluid and a velocity profile develops in a direction normal to the inviscid flow velocity. This 
flow is called a crossflow (figure 56). The crossflow velocity profile has a zero velocity at the wall and at the boundary layer edge, with an inflection point in between. The inflection point makes this velocity profile dynamically unstable and causes cross flow vortices. The direction of rotation of the vortices is in a plane normal to the streamline direction. For the NACA 0012 swept wing tip at the conditions of the experiment, the crossflow instability is the only instability that may be present near the leading edge where the ice accretion is formed.

No conclusive evidence was obtained of the presence of crossflow vortices in the present experiment, but the strong dependence of the scallops on the sweep angle for same tunnel conditions (as in the special case for $15^{\circ}$ sweep angle discussed above), the presence of complete scallops for the tunnel conditions where cross-flow vortices are expected to be stronger, and the observation on the castings of a wavelength separation at the base of the feathers (beginning of the growth of the roughness elements into feathers), suggest that they may be considered as one of the possible mechanisms that trigger the roughness elements into glaze ice feathers for the sweep angles of $30^{\circ}$ and $45^{\circ}$. The photographic data for the $45^{\circ}$ sweep angle showed that the roughness elements are of a diameter at least 1 millimeter $(0.5$ millimeters in height using the correlation between height and diameter from studies on $2 \mathrm{D}$ wings). The data for $15^{\circ}$ and $30^{\circ}$ sweep angles points towards an upper bound of 1.6 millimeters for the diameter of the roughness elements $(0.8$ in height). These roughness elements are much larger that the typical roughness elements considered in boundary layer stability studies, and it is expected that they are of the order of magnitude of the boundary layer thickness or larger. The effect on boundary layer instabilities of roughness elements of the size found in these ice accretion is not known. It is suggested that the role of the cross flow vortices should be explored further and test should be conducted on a swept wing model with roughness elements of the size observed in swept wing ice accretions, to determine if cross flow vortices play a role in scallop formation.

\section{Summary and Implications for Icing}

An experiment was conducted to understand the physical mechanisms that lead to the formation of scallops on swept wings. Icing runs were performed on a NACA 0012 swept wing tip at $45^{\circ}, 30^{\circ}$, and $15^{\circ}$ sweep angles. The following base case was chosen to study the time history of scallop formation: $45^{\circ}$ sweep angle, $150 \mathrm{mph}, 25^{\circ} \mathrm{F}, 0.75 \mathrm{~g} / \mathrm{m}^{3} \mathrm{LWC}$ and 20 $\mu \mathrm{m}$ MVD for ice accretion times of $0.5,1,2,3,4,5,6$, $7,8,9,10$ and 12 minutes. Direct measurements of scallop height and spacing, castings, video data and close-up microphotography data were obtained. For comparison with the base case, tests were run at sweep angles of $30^{\circ}$ and $15^{\circ}$ with the other conditions the same as the base case, but for ice accretion times of $2,5,8$ and 10 minutes. For the $15^{\circ}$ sweep angle, a special case of scallop formation on the endcap of the airfoil was studied. Additional icing runs were carried out to study the velocity effect, the temperature effect, and the LWC effect on the formation of the scallops. Measurements of scallop height and spacing versus ice accretion time were performed. Measurements of the distance from the attachment line to the point beyond which the roughness elements become glaze ice feathers were taken several conditions.

The results showed that the beginning of the ice accretion is similar to what has been observed for a non-swept wing. The scallops are made of glaze ice feathers that grow from roughness elements located beyond a given distance from the attachment line. To develop into feathers, the roughness elements have to reach an average diameter of at least 1 millimeter. The distance from the attachment line beyond which the roughness elements develop into scallops depends on tunnel conditions and sweep angle. This distance is the critical parameter in the formation of the scallops, it determines if complete scallops, incomplete scallops or no scallops are going to be formed. If all the elements develop into glaze ice feathers complete scallops develop, otherwise incomplete scallops will appear. In complete scallops, the feathers show a preferred direction of growth that is perpendicular to the streamlines. The feathers join along the preferred direction to form ridges, which constitutes incipient scallops. The ridges grow to form scallop tips. The feathers along the attachment line join with other feathers along the attachment line to form areas of solid ice. The scallop tips grow in size by joining with other scallop tips at the top of the feathers that form them, in this way the spacing between scallops is enhanced. For incomplete scallops, two ice zones appear, the attachment line zone and the glaze ice feathers zone. Which zone prevails depends on the conditions. For some conditions the attachment line dominates, and as the ice accretion time increases, the ice of the attachment line zone covers the feathers of the glaze ice feathers zone. The feathers of the glaze ice feathers zone 
show a preferred direction of growth and before they are totally covered by the ice of the attachment line zone, they form ice structures identical to tips of scallops if the preferred angle of direction of the feathers at the end of the zone (which is perpendicular to the streamlines) is not aligned too close with the attachment line direction. When they form scallop tips, the same mechanism of growth of the tips that was observed for complete scallops appears and creates the spacing between the tips. When the ice of the attachment line prevails, it eventually covers eventually all the feathers and they cease to play a role in the formation of the ice accretion. For cases where the glaze ice feather zone prevails, the scallop tips grow in size and dominate the ice accretion shape. For the same tunnel conditions, the scallops showed a strong dependence on sweep angle. The velocity, temperature and LWC have a strong influence on the formation of the scallops. Scallop height was measured as increasing linearly with ice accretion time. Scallop spacing was identified as an average quantity, and it was found to decrease rapidly in the first two minutes and then decrease linearly. The physical mechanisms that make the roughness elements located beyond a given distance from the attachment line to grow into glaze ice feathers are not known. It is suggested that furthers studies should be carry out to establish if the crossflow instability is one of the mechanisms playing a role in the formation of complete scallops.

The observation that the scallops are made of glaze ice feathers that grow from roughness elements located beyond a given distance from the attachment line has important consequences for icing because it ties scallop formation with local effects on 3D roughness elements. The critical parameter in scallop formation is the distance from the attachment line beyond which roughness elements develop into scallops. It is the critical parameter in scallop formation because it determines if complete scallops, incomplete scallops, or no scallops are going to be formed. If the mechanisms of heat enhancement can be identified and studied, it will allow to incorporate into the 3D ice accretions codes a parameter or parameters that will allow the code to predict the critical distance and consequently whether scallops are going to form, and if so which type. Coupling this information with models that incorporate some or all of the understanding that we have gained of complete scallops and incomplete scallop formation will allow the code to make a prediction of the ice accretion shape. In order to identify the physical mechanisms that are causing the roughness elements to develop into glaze ice feathers, further research is needed into the effect of roughness elements of the sizes encountered in the formation of the scallops on the 3D boundary layer, and on boundary layer instabilities. The role of crossflow instability in the formation of complete scallops needs to be clarified. Studies of flow field and heat transfer are needed before further progress can be made. It is hoped that the work presented here will help other researchers in the development of models of scallop formation that can be implemented into 3D ice accretion codes.

\section{Acknowledgments}

The authors would like to thank Dr. Mark Potapczuk for his advice on the experiment; Dr. HaeOk Lee for her unwavering support of the project; Mr. Andrew Rehoorst and Mr. Colin Bidwell for their assistance with past work on scallops; Dr. William Wright for his help with LEWICE 2D; Mr. William Sexton, Mr. Dave Sheldon and all the personnel at the Icing Research Tunnel for their help in all phases of the experiment; Mr. Jeffrey Williams for his help with the castings. We would also like to thank the personnel of the Imaging Technology Center for their assistance with the photographic work.

\section{References}

Wilder, R.W., "A Theoretical and Experimental Means to Predict Ice Accretion Shapes for Evaluating Aircraft Handling and Performance Characteristics", AGARD Report No. 127 (Aircraft lcing), Ottawa, Canada, 1977.

${ }^{2}$ Pierre, M. and Vaucheret, X., "Icing Test Facilities and Test Techniques in Europe", AGARD Report No. 127 (Aircraft lcing), Ottawa, Canada, 1977.

${ }^{3}$ Laschka, B. and Jesse, R.E., "Ice Accretion and its Effects on Aerodynamics of Unprotected Aircraft Components", AGARD Report No. 127 (Aircraft lcing), Ottawa, Canada, 1977.

4 Reehorst, A.L., "Prediction of Ice Accretion on a Swept NACA 0012 Airfoil and Comparisons to Flight Test Results", AIAA Paper 92-0043, Jan. 1992.

5 Reehorst, A.L. and Bidwell, C., NASA Lewis Research Center internal document, 1991.

${ }^{B}$ Hedde, T. and Guffond, D., "Improvement of the ONERA 3D Icing Code, Comparison with 3D 
Experimental Shapes", AIAA Paper 93-0169, Jan. 1993.

${ }^{7}$ Olsen, W. and Walker, E., "Experimental Evidence for Modifying the Current Physical Model for Ice Accretion on Aircraft Surfaces", NASA TM-87184, May 1996.

- Saric, W.S., "Laminar-Turbulent Transition: Fundamentals", AGARD Report No. 786 (Special Course on Skin Friction Drag Reduction), RhodeSt.Genese, Belgium, 1992.

${ }^{9}$ Reed, H.L. and Saric, W.S., "Stability of ThreeDimensional Boundary Layers", Ann. Rev. Fluid Mechanics, Vol.21, pp. 235-284, 1989.

${ }^{10}$ Dagenhart, J.R., Saric, W.S., Mousseux, M. and Stack, J.P. "Crossflow-Vortex Instability and Transition on a 45-Degree Swept Wing", AIAA Paper No. 89-1892, June 1989.

1 Arnal, D., "Three-Dimensional Boundary Layers: Laminar-Turbulent Transition", AGARD Report No. 741 (Computation of Three-Dimensional Boundary Layers Including Separation), Rhode-St.Genese, Belgium, 1986.

12 Poll, D.I.A., "Transition Description and Prediction in Three-Dimensional Flows", AGARD Report No. 709 (Special Course on Stability and Transition of Laminar Flows), VKI, Brussels, 1984. 


\begin{tabular}{|c|c|c|c|c|c|c|c|}
\hline Run Number & Sweep Angle & Angle of Attack & $\begin{array}{l}\text { Velocity } \\
\text { (mph) }\end{array}$ & $\begin{array}{c}\text { Temperature } \\
\left({ }^{\circ} \mathrm{F}\right)\end{array}$ & $\begin{array}{l}\text { LWC } \\
\left(g / m^{3}\right)\end{array}$ & $\begin{array}{l}\text { MVD } \\
(\mu \mathrm{m})\end{array}$ & $\begin{array}{c}\text { Ice Accretion } \\
\text { Time } \\
\text { (min) }\end{array}$ \\
\hline 061896.01 & 45 & 0 & 150 & 25 & 0.75 & 20 & 12 \\
\hline 061896.02 & 45 & 0 & 150 & 25 & 0.75 & 20 & 0.5 \\
\hline 061896.03 & 45 & 0 & 150 & 25 & 0.75 & 20 & 1 \\
\hline O61896.04 & 45 & 0 & 150 & 25 & 0.75 & 20 & 2 \\
\hline 061896.05 & 45 & 0 & 150 & 25 & 0.75 & 20 & 3 \\
\hline 061896.06 & 45 & 0 & 150 & 25 & 0.75 & 20 & 4 \\
\hline 061996.01 & 45 & 0 & 150 & 25 & 0.75 & 20 & 4 \\
\hline 061996.02 & 45 & 0 & 150 & 25 & 0.75 & 20 & 5 \\
\hline 061996.03 & 45 & 0 & 150 & 25 & 0.75 & 20 & 6 \\
\hline 061996.04 & 45 & 0 & 150 & 25 & 0.75 & 20 & 7 \\
\hline 061996.05 & 45 & 0 & 150 & 25 & 0.75 & 20 & 8 \\
\hline 061996.06 & 45 & 0 & 150 & 25 & 0.75 & 20 & 9 \\
\hline 061996.07 & 45 & 0 & 150 & 25 & 0.75 & 20 & 10 \\
\hline O61996.08 & 45 & 0 & 150 & 25 & 0.75 & 20 & 12 \\
\hline 062096.01 & 30 & 0 & 150 & 25 & 0.75 & 20 & 2 \\
\hline 062096.02 & 30 & 0 & 150 & 25 & 0.75 & 20 & 5 \\
\hline 062096.03 & 30 & 0 & 150 & 25 & 0.75 & 20 & 8 \\
\hline 062096.04 & 30 & 0 & 150 & 25 & 0.75 & 20 & 10 \\
\hline 062096.05 & 15 & 0 & 150 & 25 & 0.75 & 20 & 2 \\
\hline 062096.06 & 15 & 0 & 150 & 25 & 0.75 & 20 & 5 \\
\hline 062096.07 & 15 & 0 & 150 & 25 & 0.75 & 20 & 8 \\
\hline 062096.08 & 15 & 0 & 150 & 25 & 0.75 & 20 & 11.6 \\
\hline 062196.01 & 30 & 0 & 200 & 25 & 0.75 & 20 & 10 \\
\hline 062196.02 & 30 & 0 & 250 & 25 & 0.75 & 20 & 10 \\
\hline 062196.03 & 45 & 0 & 100 & 25 & 0.75 & 20 & 10 \\
\hline 062196.04 & 45 & 0 & 250 & 25 & 0.75 & 20 & 10 \\
\hline 062196.05 & 15 & 0 & 250 & 25 & 0.75 & 20 & 10 \\
\hline 062196.06 & 15 & 0 & 200 & 25 & 0.75 & 20 & 10 \\
\hline 070196.01 & 45 & 0 & 150 & 20 & 0.75 & 20 & 2 \\
\hline 070196.02 & 45 & 0 & 150 & 20 & 0.75 & 20 & 5 \\
\hline 070196.03 & 45 & 0 & 150 & 20 & 0.75 & 20 & 8 \\
\hline 070196.04 & 45 & 0 & 150 & 20 & 0.75 & 20 & 10 \\
\hline 070196.05 & 45 & 0 & 150 & 10 & 0.75 & 20 & 2 \\
\hline 070196.06 & 45 & 0 & 150 & 10 & 0.75 & 20 & 5 \\
\hline 070296.01 & 30 & 0 & 150 & 25 & 0.50 & 20 & 10 \\
\hline 070296.02 & 30 & 0 & 150 & 25 & 1.25 & 20 & 10 \\
\hline 070296.03 & 15 & 0 & 150 & 25 & 0.50 & 20 & 10 \\
\hline 070296.04 & 15 & 0 & 150 & 25 & 1.25 & 20 & 10 \\
\hline 070296.05 & 15 & 0 & 200 & 25 & 0.50 & 20 & 10 \\
\hline 070396.01 & 45 & 0 & 100 & 25 & 0.75 & 20 & 15 \\
\hline 070396.02 & 30 & 0 & 150 & 29 & 0.75 & 20 & 10 \\
\hline 070396.03 & 30 & 0 & 150 & 29 & 0.50 & 20 & 15 \\
\hline 070396.04 & 30 & 0 & 150 & 29 & 1.25 & 20 & 10 \\
\hline 070396.05 & 15 & 0 & 200 & 25 & 1.00 & 20 & 10 \\
\hline 070396.06 & 15 & 0 & 150 & 29 & 0.75 & 20 & 10 \\
\hline O70396.07 & 15 & 0 & 150 & 29 & 0.50 & 20 & 15 \\
\hline
\end{tabular}

Table 1. Test Matrix for the icing runs

\begin{tabular}{|c|c|c|c|c|c|c|c|}
\hline Run Number & Sweep Angle & $\begin{array}{c}\text { Critical } \\
\text { Distance } \\
(\mathrm{mm})\end{array}$ & $\begin{array}{c}\text { Velocity } \\
(\mathrm{mph})\end{array}$ & $\begin{array}{c}\text { Temperature } \\
\left({ }^{\circ} \mathrm{F}\right)\end{array}$ & $\begin{array}{c}\text { LWC } \\
\left(\mathrm{g} / \mathrm{m}^{3}\right)\end{array}$ & $\begin{array}{c}\text { MVD } \\
(\mu \mathrm{m})\end{array}$ & $\begin{array}{c}\text { Ice Accretion } \\
\text { Time } \\
(\mathrm{min})\end{array}$ \\
\hline 062196.03 & 45 & 0 & 100 & 25 & 0.75 & 20 & 10 \\
\hline 061896.04 & 45 & 0 & 150 & 25 & 0.75 & 20 & 2 \\
\hline 062196.04 & 45 & 0 & 250 & 25 & 0.75 & 20 & 10 \\
\hline 062096.01 & 30 & 6 & 150 & 25 & 0.75 & 20 & 2 \\
\hline 062196.01 & 30 & 2 & 200 & 25 & 0.75 & 20 & 10 \\
\hline 062196.02 & 30 & 0 & 250 & 25 & 0.75 & 20 & 10 \\
\hline 062096.05 & 15 & 10.1 & 150 & 25 & 0.75 & 20 & 2 \\
\hline 062196.05 & 15 & 6.8 & 250 & 25 & 0.75 & 20 & 10 \\
\hline 062196.06 & 15 & 4 & 200 & 25 & 0.75 & 20 & 10 \\
\hline
\end{tabular}

Table 2. Values of critical distance, measured from attachment line to beginning of glaze ice feathers zone 


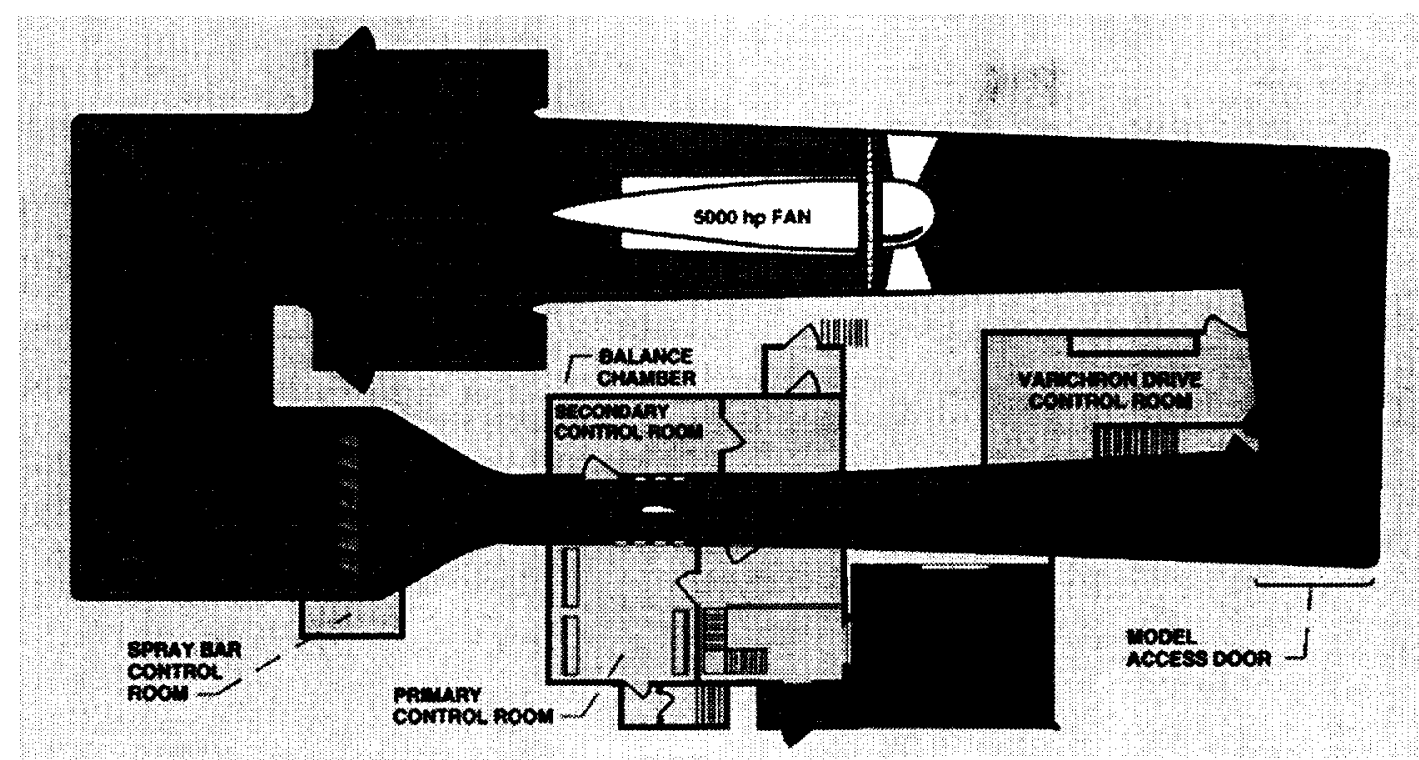

Figure 1. NASA Lewis Icing Research Tunnel, Plan view.

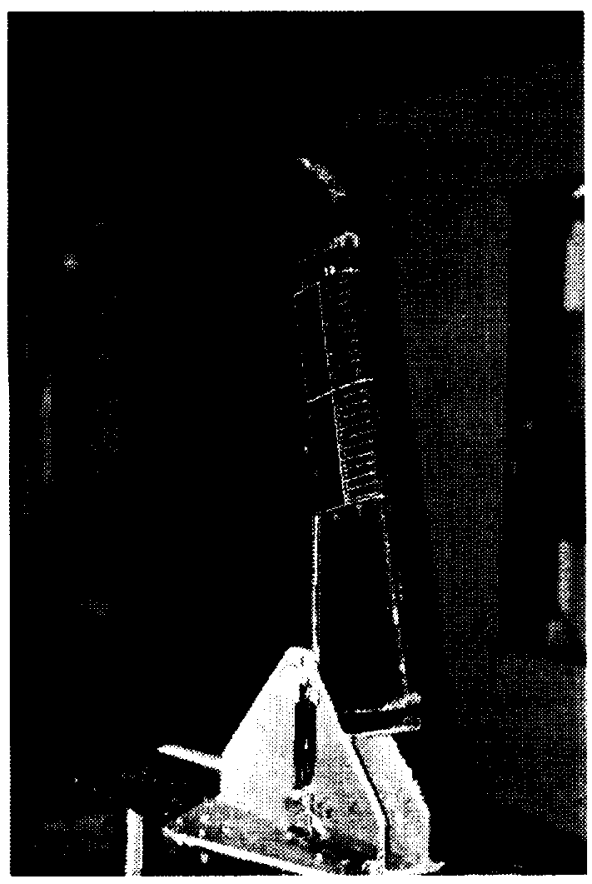

Figure 2. NACA 0012 swept wing tip in the IRT Test Section

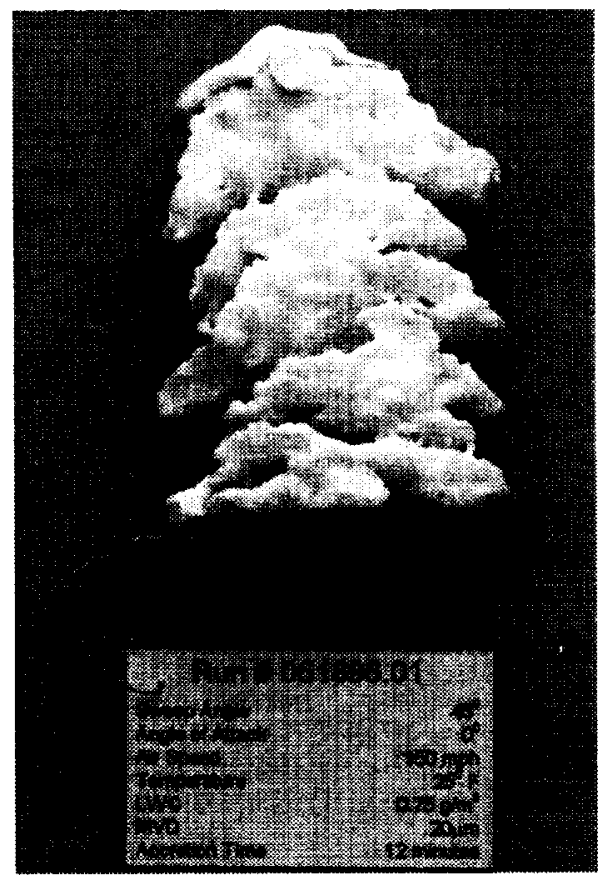

Figure 3. Example of Urethane casting of a scallop formation. 


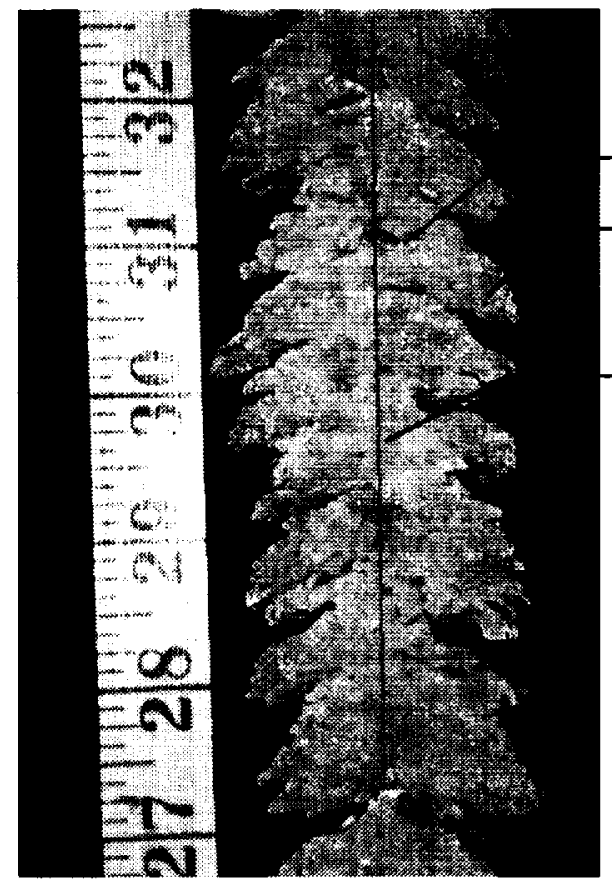

Figure 4. Front view of ice accretion for base case, showing large pointed ice structures called scallops. $\Lambda=45^{\circ}, V=150 \mathrm{mph}, T=25^{\circ} \mathrm{F}$, $L W C=0.75 \mathrm{~g} / \mathrm{m}^{3}, \quad M V D=20 \mu \mathrm{m}, \quad \tau=12 \mathrm{~min}$. Direction of flow is from bottom to top, scale of ruler is in inches.

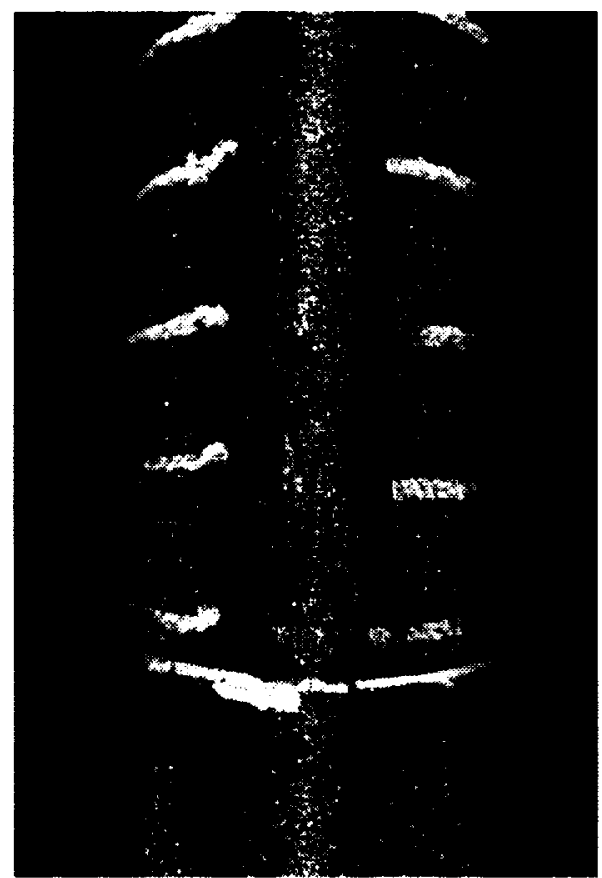

Figure 6. Front vlew of ice accretion at 0.5 minute, showing the thin layer of ice covered with roughness elements. $\Lambda=45^{\circ}, V=150 \mathrm{mph}$, $T=25^{\circ} \mathrm{F}, \quad L W C=0.75 \mathrm{~g} / \mathrm{m}^{3}, \quad M V D=20 \mu \mathrm{m}$, $\tau=0.5 \mathrm{~min}$. Direction of flow is from bottom to top, separation between stripes is approximately $13 \mathrm{~mm}$.

\section{Base of scallop}

Tip of scallop

Approximate

location of

attachment line

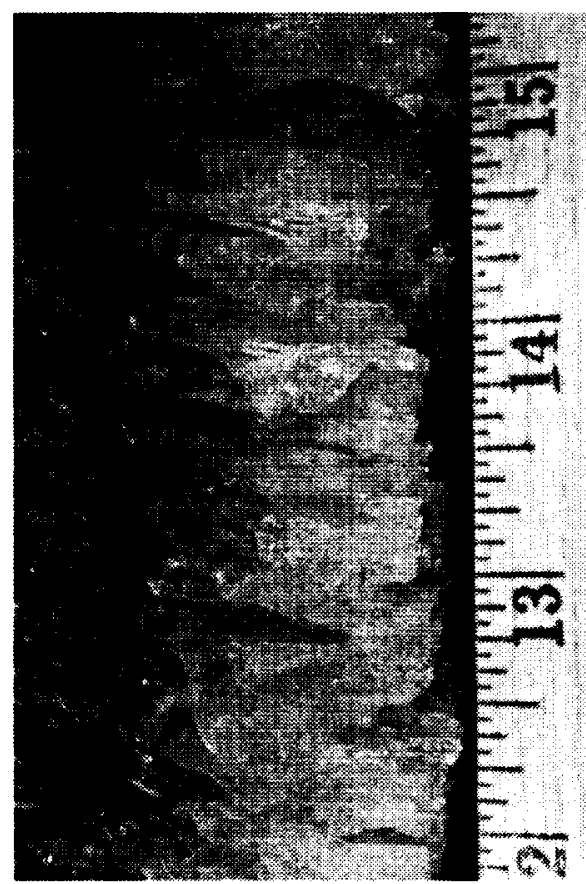

Figure 5. Side view of ice accretion for base case, showing the glaze ice feathers that form the scallops. $\Lambda=45^{\circ}, V=150 \mathrm{mph}, T=25^{\circ} \mathrm{F}$, $\mathrm{LWC}=0.75 \mathrm{~g} / \mathrm{m}^{3}, \quad \mathrm{MVD}=20 \mu \mathrm{m}, \quad \tau=12 \mathrm{~min}$ Direction of flow is from bottom to top, scale of ruler is in inches.

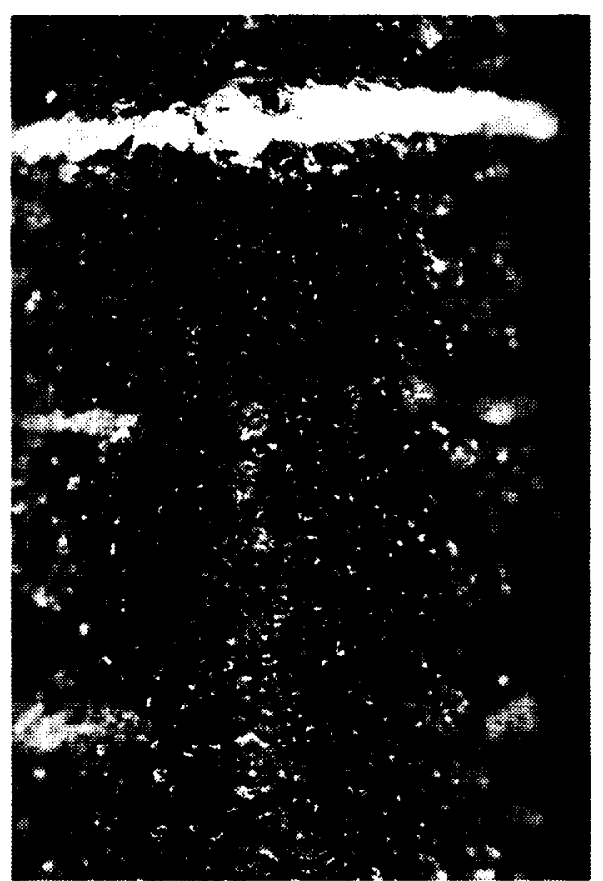

Figure 7. Close-up view of lce accretion at 1 minute, showing roughness elements. $\Lambda=45^{\circ}$, $V=150 \quad \mathrm{mph}, \quad T=25^{\circ} \mathrm{F}, \quad L W C=0.75 \mathrm{~g} / \mathrm{m}^{3}$, $M V D=20 \mu \mathrm{m}, \tau=1 \mathrm{~min}$. Direction of flow is from bottom to top, separation between stripes is approximately $13 \mathrm{~mm}$. 


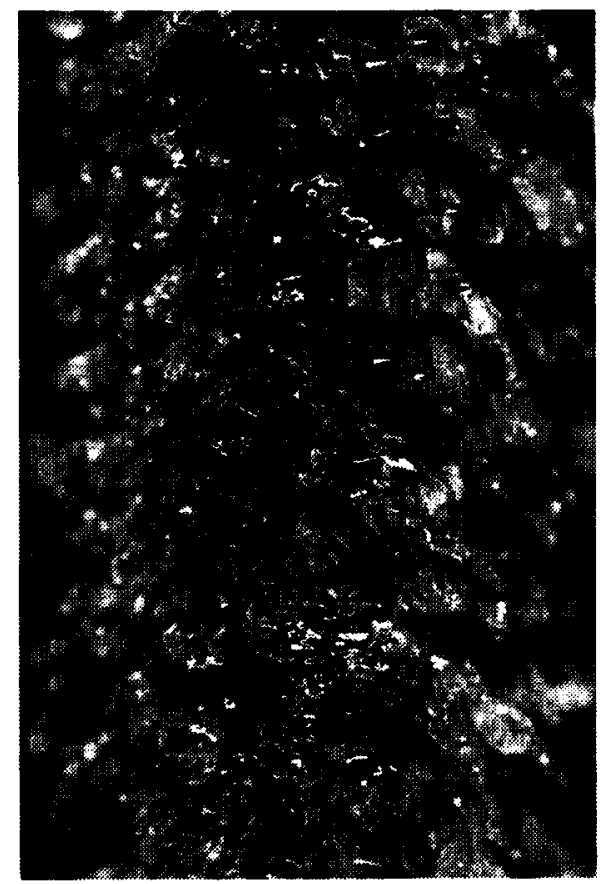

Figure 8. Feathers covering all the ice accretion at 2 minutes. $\Lambda=45^{\circ}, V=150 \mathrm{mph}$, $T=25^{\circ} \mathrm{F}, \quad L W C=0.75 \mathrm{~g} / \mathrm{m}^{3}, M V D=20 \mu \mathrm{m}, \tau=2 \mathrm{~min}$. Direction of flow is from bottom to top, separation between stripes is approximately 13 $\mathrm{mm}$.

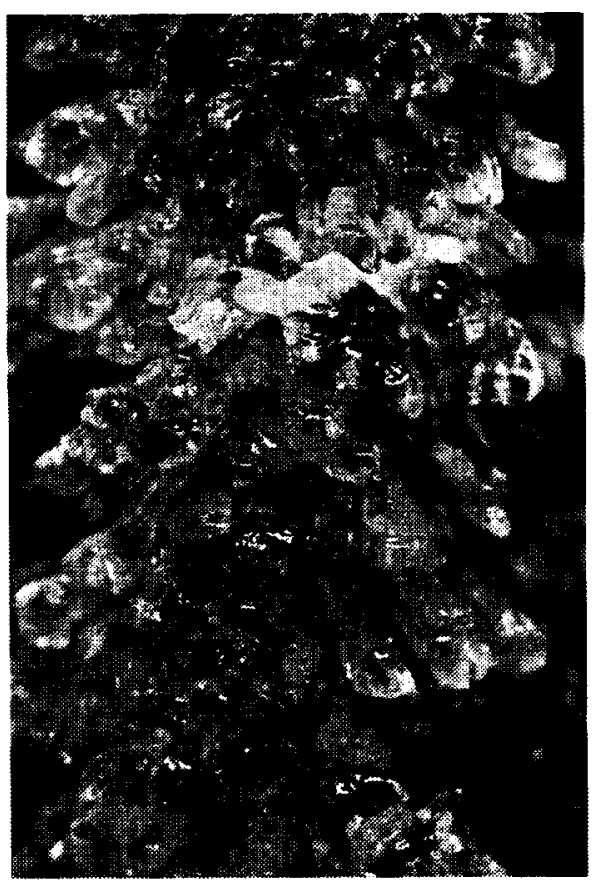

Figure 10. Close-up view of feathers at ice accretion time of 3 minutes. $\Lambda=45^{\circ}, V=150$ $\mathrm{mph}, T=25^{\circ} \mathrm{F}, \quad L W C=0.75 \mathrm{~g} / \mathrm{m}^{3}, \quad M V D=20 \mu \mathrm{m}$, $\tau=3 \mathrm{~min}$. Direction of flow is from bottom to top, separation between stripes is approximately 13 $\mathrm{mm}$.

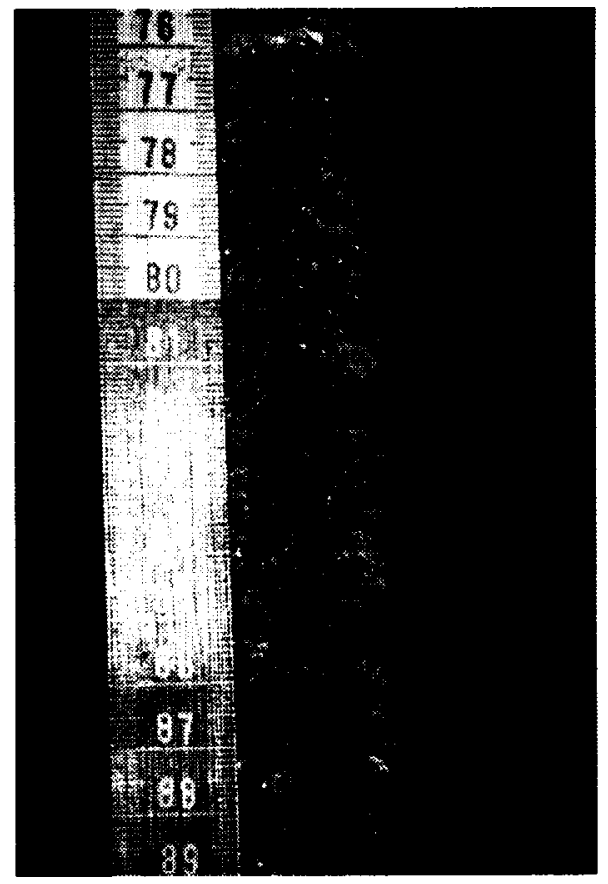

Figure 9. Front view of ice accretion at 3 minutes, showing incipient scallops. $\Lambda=45^{\circ}$ $V=150 \quad \mathrm{mph}, \quad T=25^{\circ} \mathrm{F}, \quad L W C=0.75 \mathrm{~g} / \mathrm{m}^{3}$, $M V D=20 \mu \mathrm{m}, \tau=3 \mathrm{~min}$. Direction of flow is from bottom to top, scale of ruler is in centimeters.

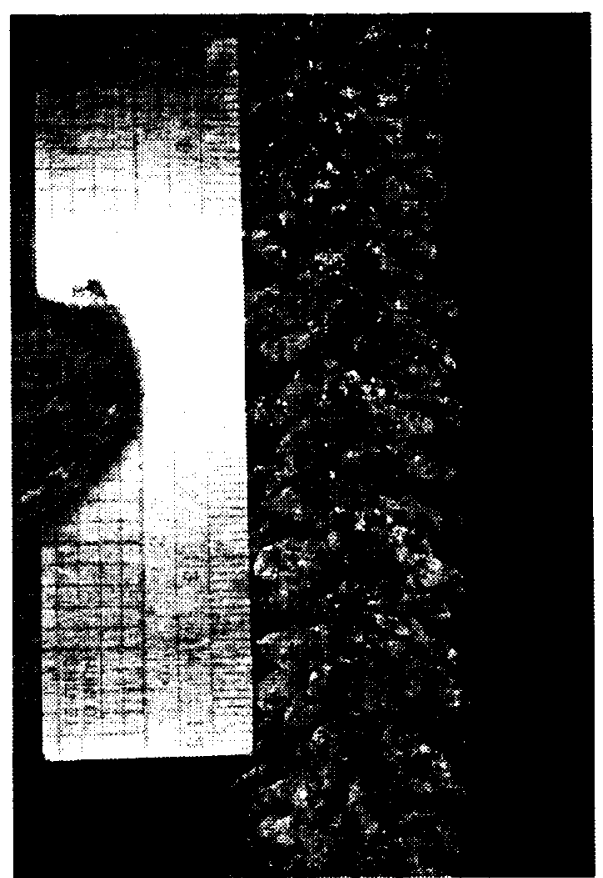

Figure 11. Front view of ice accretion at 4 minutes, showing scallops. $\Lambda=45^{\circ}, V=150 \mathrm{mph}$, $T=25^{\circ} \mathrm{F}, L W C=0.75 \mathrm{~g} / \mathrm{m}^{3}, M V D=20 \mu \mathrm{m}, \tau=4 \mathrm{~min}$. Direction of flow is from bottom to top, scale of ruler is in centimeters 


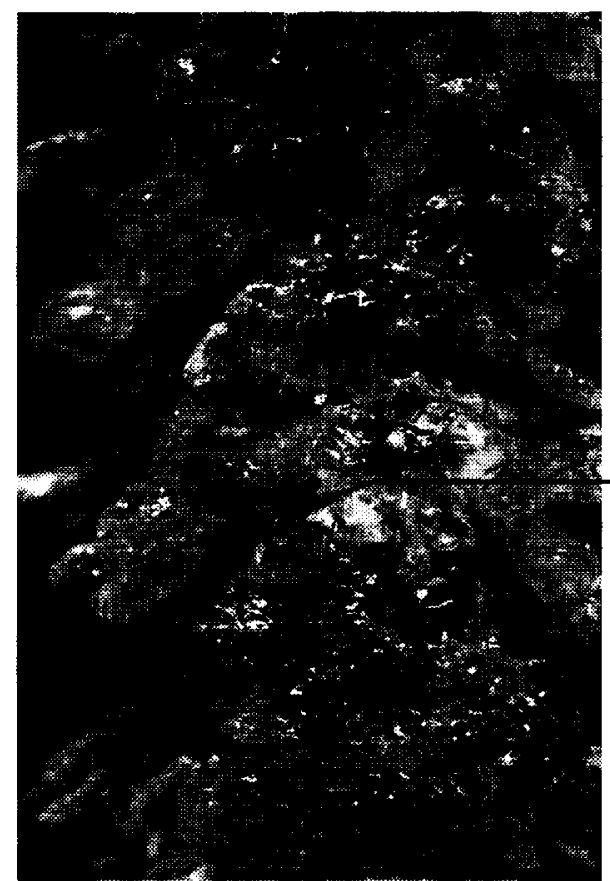

Figure 12. Close-up view of ice accretion after 4 minutes, showing the joining of feathers to form scallops and the joining of feathers along the attachment line. $\Lambda=45^{\circ}, V=150 \mathrm{mph}$, $\mathrm{T}=25^{\circ} \mathrm{F}, L W C=0.75 \mathrm{~g} / \mathrm{m}^{3}, M V D=20 \mu \mathrm{m}, \tau=4 \mathrm{~min}$. Direction of flow is from bottom to top.

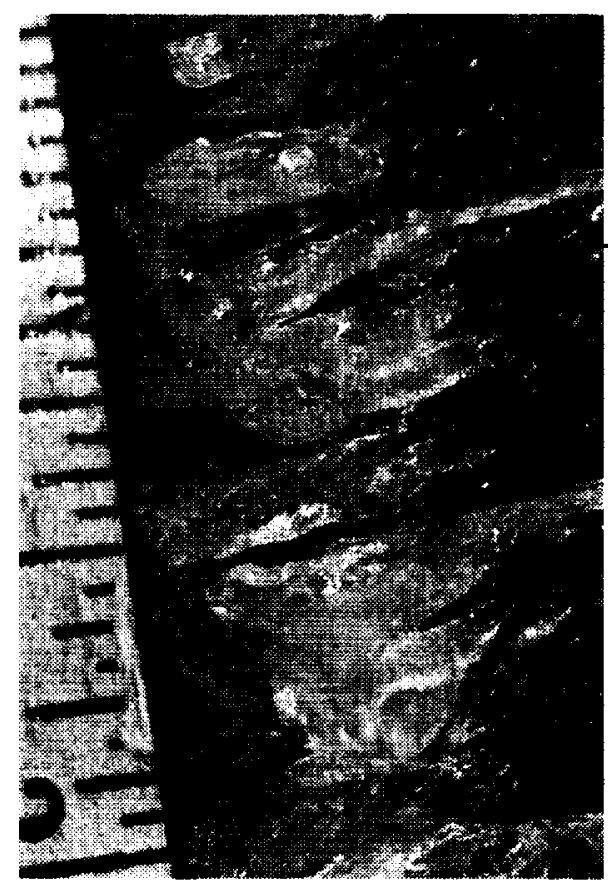

Figure 14. Side view of feathers at lce accretion time of 5 minutes, showing the joining of feathers at their tops. $\Lambda=45^{\circ}, V=150$ $\mathrm{mph}, T=25^{\circ} \mathrm{F}, \quad L W C=0.75 \mathrm{~g} / \mathrm{m}^{3}, M V D=20 \mu \mathrm{m}$, $\tau=5 \mathrm{~min}$. Direction of flow is from bottom to top, scale of ruler is in inches.
Scallop discussed in the text

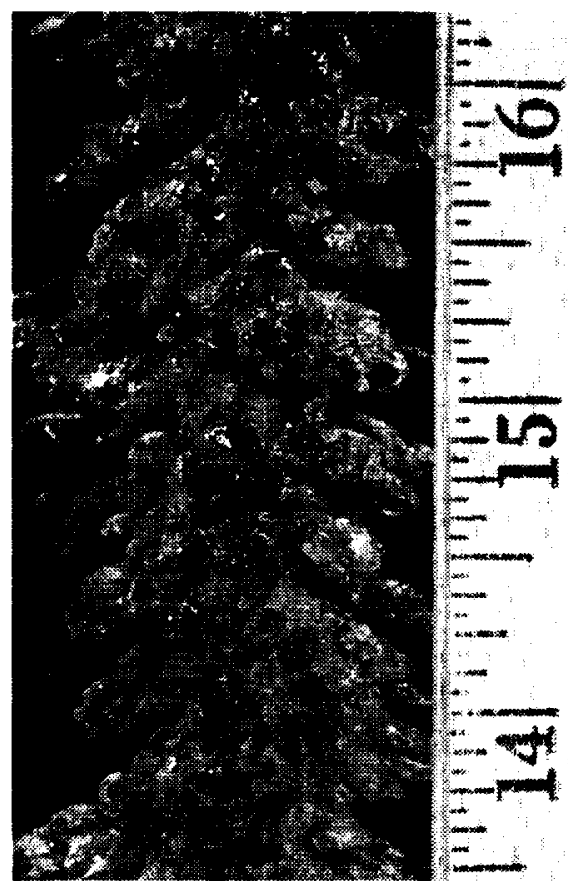

Flgure 13. Front view of ice accretion at 5 minutes, showing scallops and areas of solid ice along the attachment line area. $\Lambda=45^{\circ}$, $V=150 \quad \mathrm{mph}, \quad T=25^{\circ} \mathrm{F}, \quad L W C=0.75 \mathrm{~g} / \mathrm{m}^{3}$, $M V D=20 \mu \mathrm{m}, \tau=5 \mathrm{~min}$. Direction of flow is from bottom to top, scale of ruler is in inches.

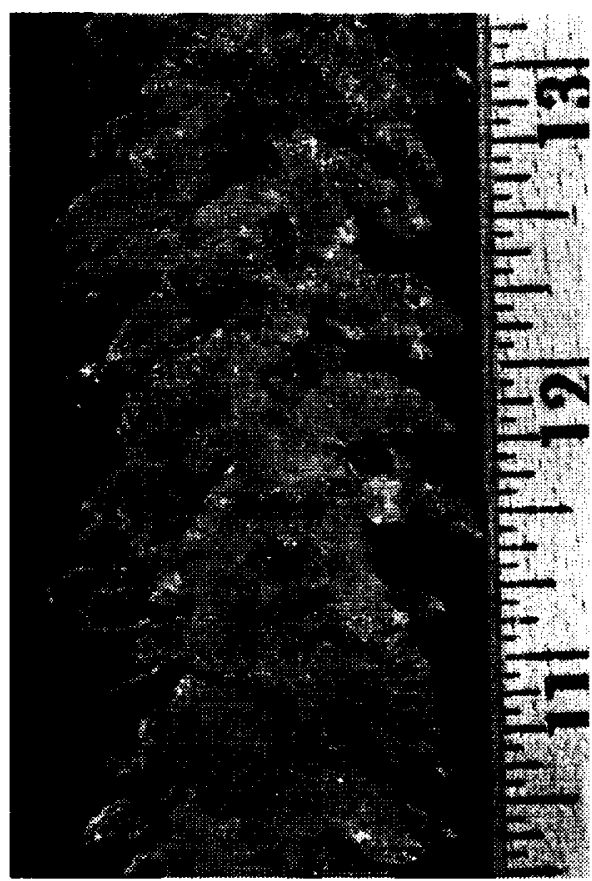

Figure 15. Front view of ice accretion at 7 minutes, showing areas of solid ice along the attachment line, and solid ice beginning to appear on the tip of the scallops. $\Lambda=45^{\circ}$, $V=150 \quad \mathrm{mph}, \quad T=25^{\circ} \mathrm{F}$, LWC $=0.75 \mathrm{~g} / \mathrm{m}^{3}$, $M V D=20 \mu \mathrm{m}, \tau=7 \mathrm{~min}$. Direction of flow is from bottom to top, scale of ruler is in inches. 


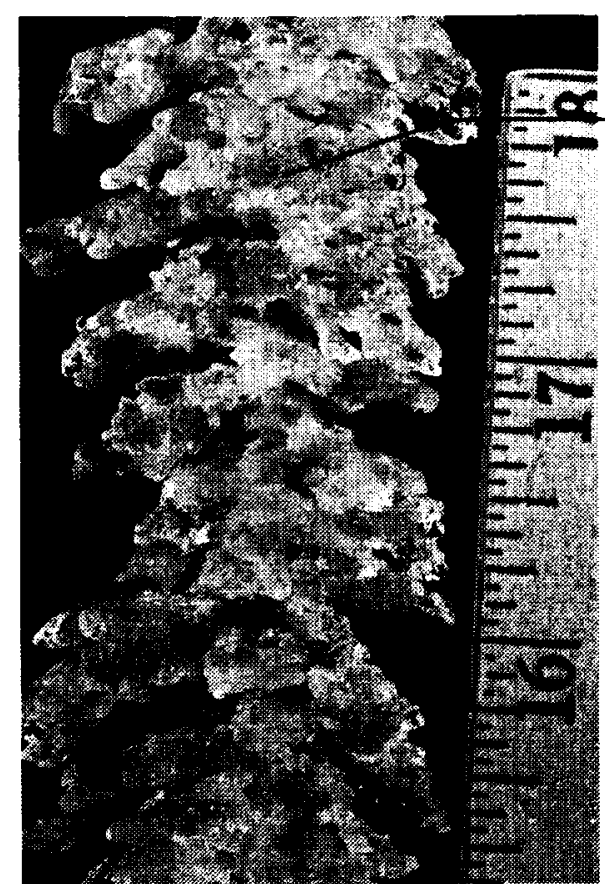

Figure 16. Front view of ice accretion at 8 minutes, showing areas of solid ice on the attachment line area and on the scallop tips. $\Lambda=45^{\circ}, V=150 \mathrm{mph}, T=25^{\circ} \mathrm{F}, L W C=0.75 \mathrm{~g} / \mathrm{m}^{3}$, $M V D=20 \mu \mathrm{m}, \tau=8 \mathrm{~min}$. Direction of flow is from bottom to top, scale of ruler is in inches.

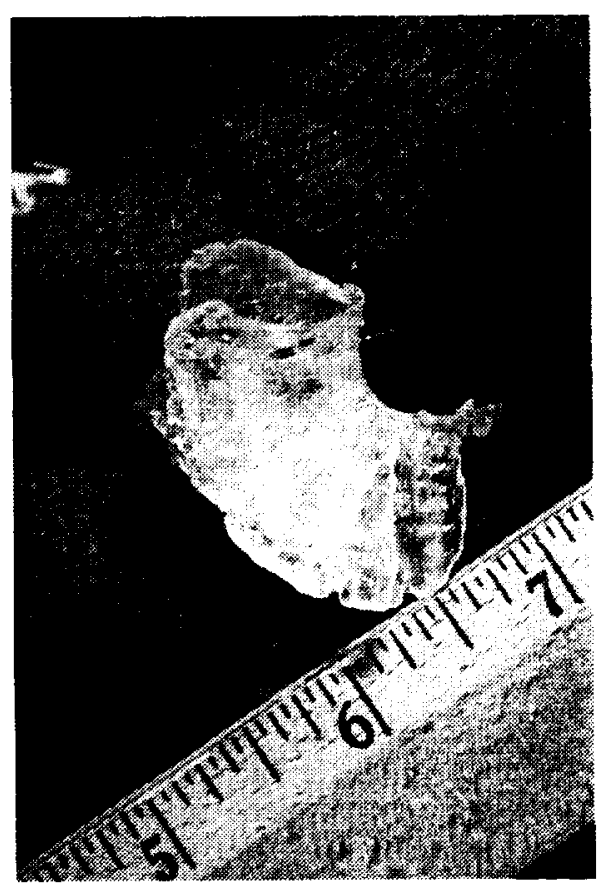

Figure 18. Isolated scallop at ice accretion time of 10 minutes, where the structure of the individual feathers can still be seen. $\Lambda=45^{\circ}$, $V=150 \quad \mathrm{mph}, \quad T=25^{\circ} \mathrm{F}, \quad L W C=0.75 \mathrm{~g}^{3}$, $M V D=20 \mu \mathrm{m}, \tau=10 \mathrm{~min}$. Scale of ruler is in inches.
Area of solid ice along the attachment line

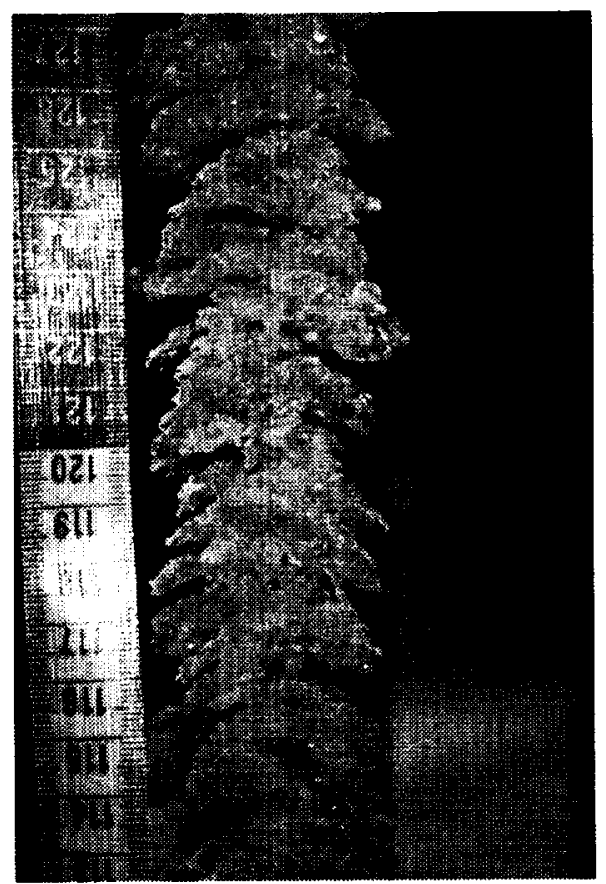

Figure 17. Front view of ice accretion at 10 minutes, showing well developed scallops. $\Lambda=45^{\circ}, V=150 \mathrm{mph}, T=25^{\circ} \mathrm{F}, \quad L W C=0.75 \mathrm{~g} / \mathrm{m}^{3}$, $M V D=20 \mu \mathrm{m}, \tau=10 \mathrm{~min}$. Direction of flow is from bottom to top, scale of ruler is in centimeters.

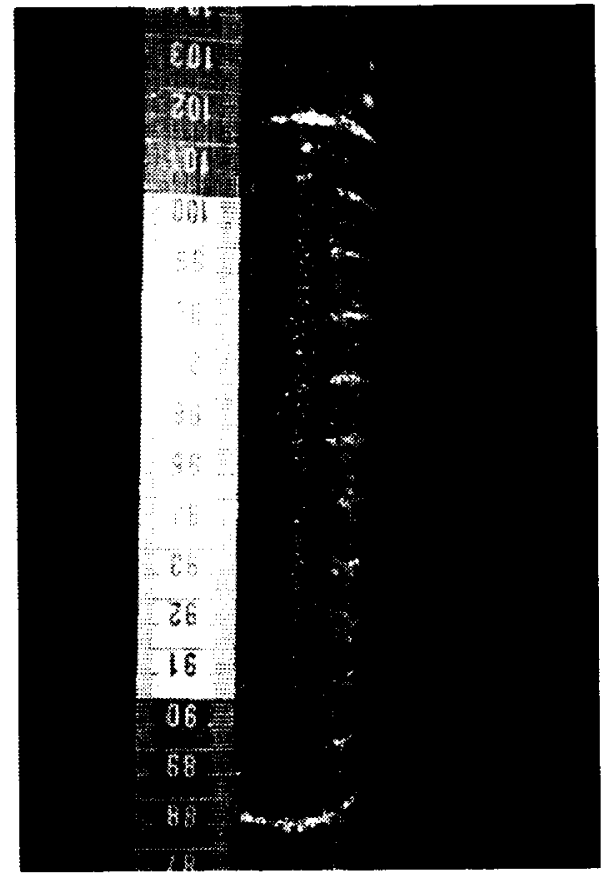

Figure 19. Front view of ice accretion at 2 minutes, showing the attachment line zone and the glaze ice feathers zone. $\Lambda=30^{\circ}, V=150$ $\mathrm{mph}, T=25^{\circ} \mathrm{F}, \quad L W C=0.75 \mathrm{~g} / \mathrm{m}^{3}, \quad M V D=20 \mu \mathrm{m}$, $\tau=2 \mathrm{~min}$. Direction of flow is from bottom to top, scale of ruler is in centimeters. 


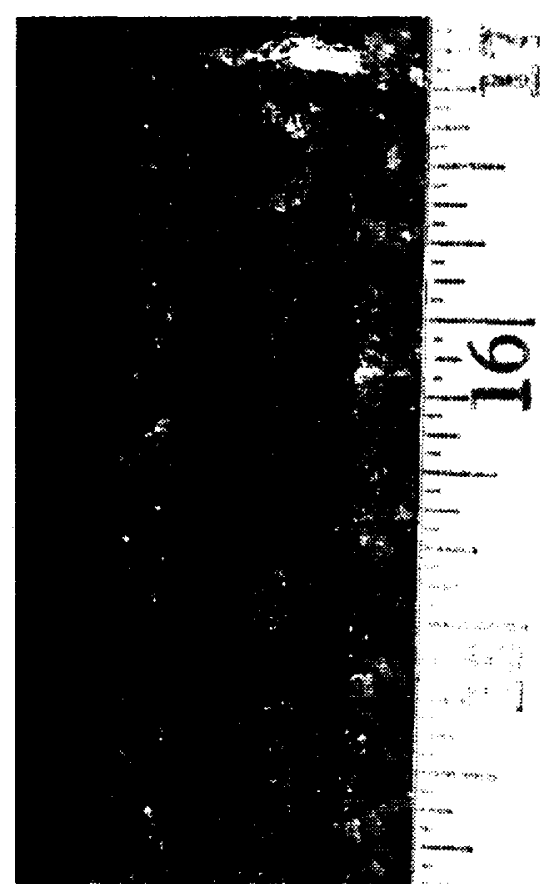

Figure 20. Close-up of ice accretion at 2 minutes, showing the roughness elements on the attachment line zone. $\Lambda=30^{\circ}, V=150 \mathrm{mph}$, $T=25^{\circ} \mathrm{F}, L W C=0.75 \mathrm{~g} / \mathrm{m}^{3}, M V D=20 \mu \mathrm{m}, \tau=2 \mathrm{~min}$. Direction of flow is from bottom to top, scale of ruler is in inches.

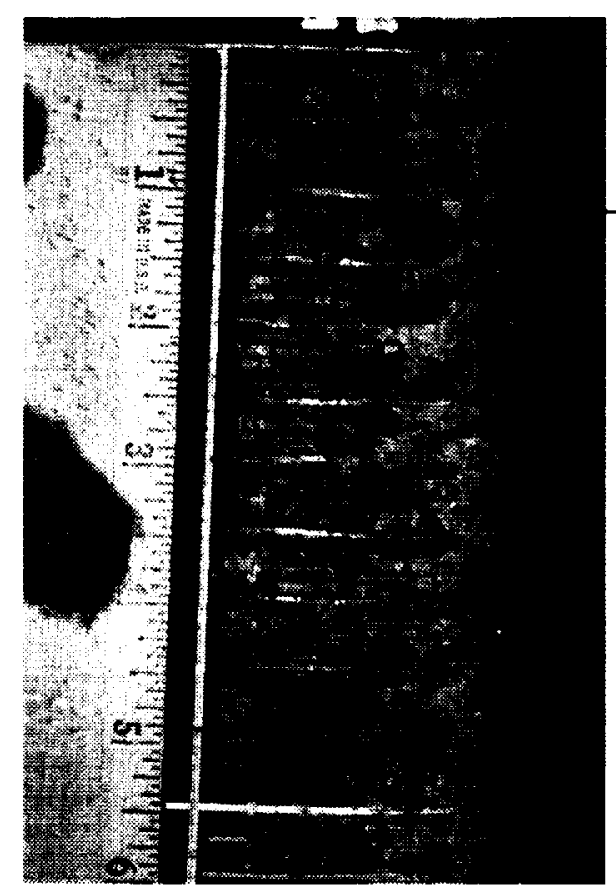

Typical ridge

Figure 22. Side view of the glaze ice feathers zone at an ice accretion time of 5 minutes. The feathers located at the end of the zone show a preferred direction of growth and form ridges. $\quad \Lambda=30^{\circ}, V=150 \mathrm{mph}, T=25^{\circ} \mathrm{F}$, LWC $=0.75 \mathrm{~g} / \mathrm{m}^{3}, \quad M V D=20 \mu \mathrm{m}, \quad \tau=5 \mathrm{~min}$, Direction of flow is from bottom to top, scale of ruler is in Inches

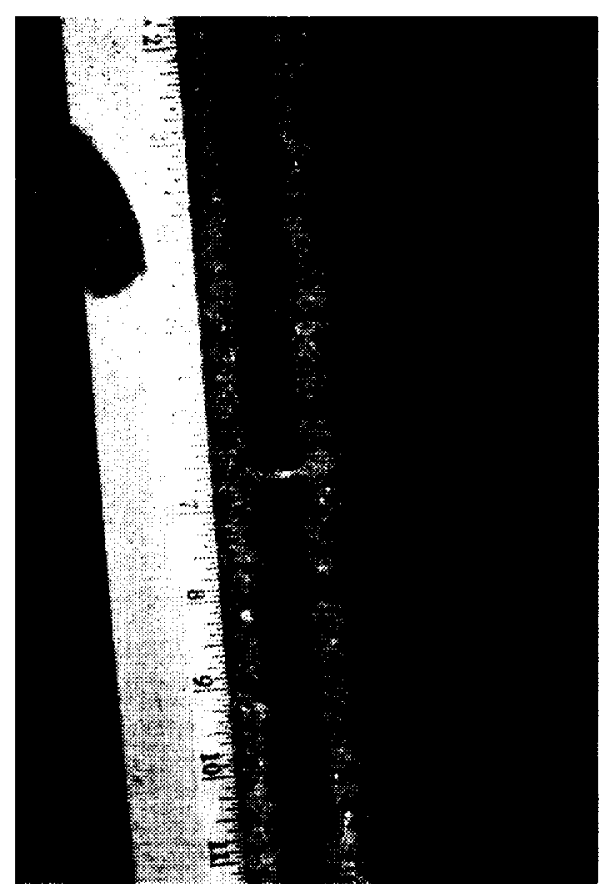

Figure 21. Front view of ice accretion at 5 minutes, showing the feathers on the glaze ice feathers zone beginning to form scallop tlps. $\Lambda=30^{\circ}, V=150 \mathrm{mph}, T=25^{\circ} \mathrm{F}, L W C=0.75 \mathrm{~g} / \mathrm{m}^{3}$, $M V D=20 \mu \mathrm{m}, \tau=5 \mathrm{~min}$. Direction of flow is from bottom to top, scale of ruler is in inches.

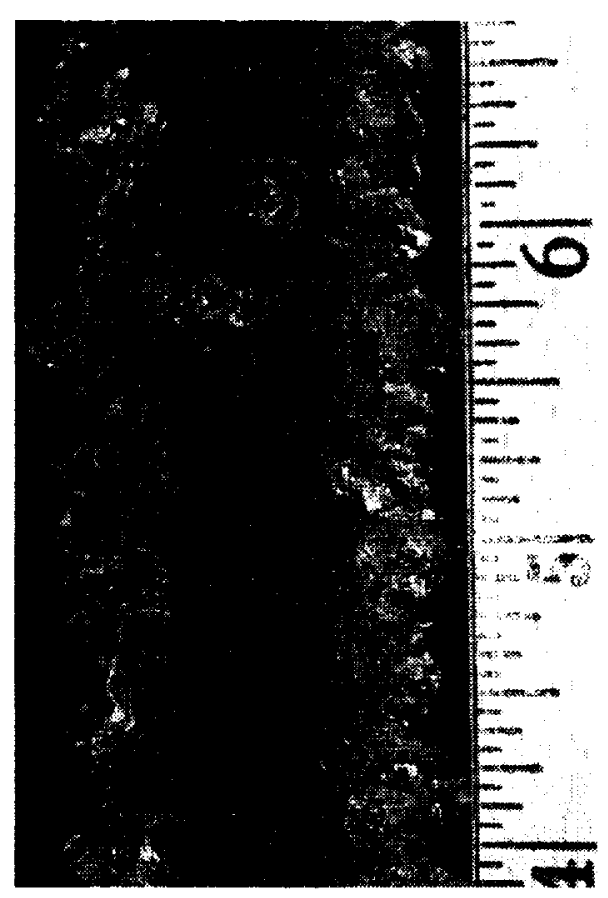

Figure 23. Close-up of ice accretion at 5 minutes, showing the ice of the attachment line zone covering the glaze ice feathers zone. $\Lambda=30^{\circ}, V=150 \mathrm{mph}, T=25^{\circ} \mathrm{F}, L W C=0.75 \mathrm{~g} / \mathrm{m}^{3}$, $M V D=20 \mu \mathrm{m}, \tau=5 \mathrm{~min}$. Scale of ruler is in inches. 


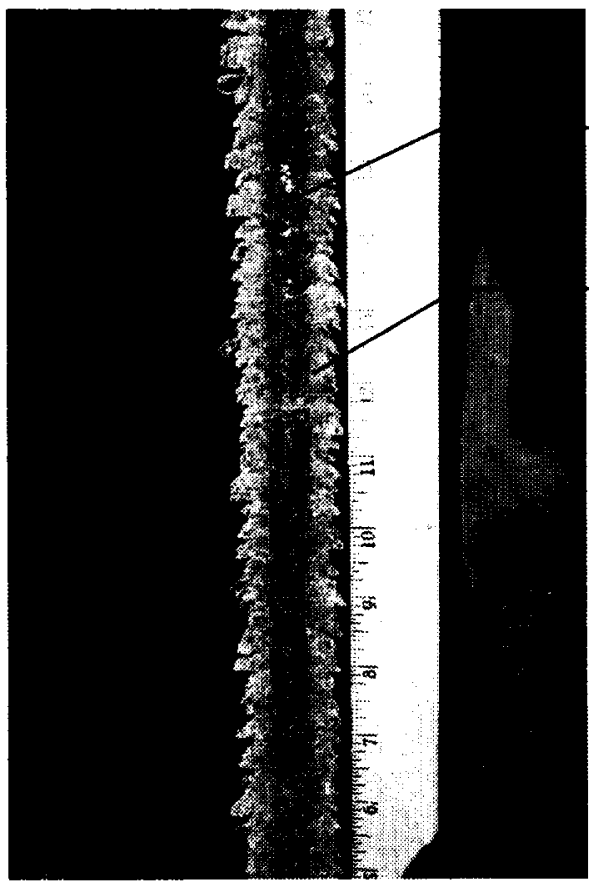

Figure 24. Front view of ice accretion at 8 minutes, showing the two zones, and the feathers of the glaze ice feathers zone forming scallop tips. $\Lambda=30^{\circ}, V=150 \mathrm{mph}, T=25^{\circ} \mathrm{F}$, LWC $=0.75 \mathrm{~g} / \mathrm{m}^{3}, \quad$ MVD $=20 \mu \mathrm{m}, \quad \tau=8 \mathrm{~min}$. Direction of flow is from bottom to top, scale of ruler is in inches.

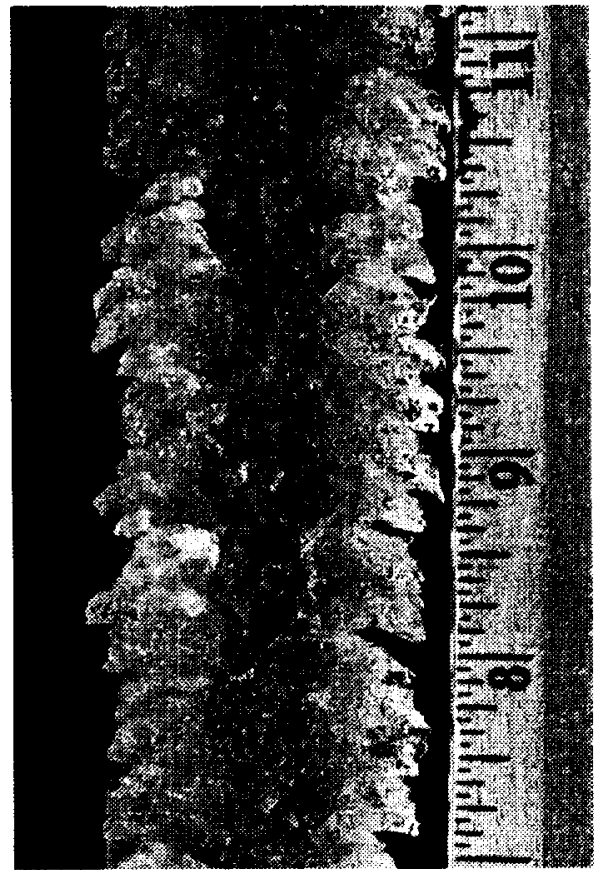

Figure 26. Front view of ice accretion at 10 minutes. $\Lambda=30^{\circ}, \quad V=150 \quad \mathrm{mph}, \quad T=25^{\circ} \mathrm{F}$, LWC $=0.75 \mathrm{~g} / \mathrm{m}^{3}, \quad M V D=20 \mu \mathrm{m}, \quad \tau=10 \mathrm{~min}$ Direction of flow is from bottom to top, scale of ruler is in inches.
Attachment line zone

Glaze ice

feathers zone

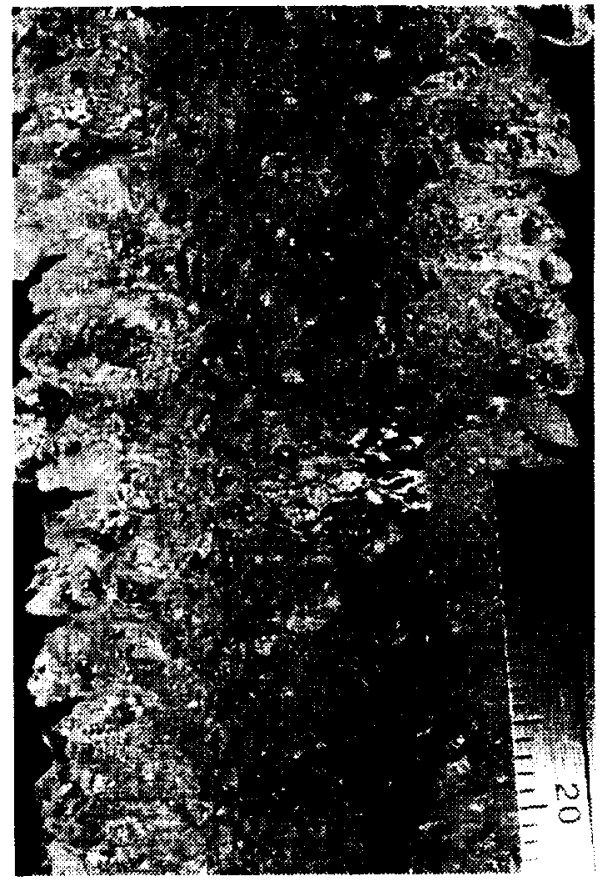

Figure 25. Close-up of ice accretion at 8 minutes, showing ice of the attachment line zone covering the glaze ice feathers zone. $\Lambda=30^{\circ}, V=150 \mathrm{mph}, T=25^{\circ} \mathrm{F}, L W C=0.75 \mathrm{~g} / \mathrm{m}^{3}$, $M V D=20 \mu \mathrm{m}, \tau=8 \mathrm{~min}$. Direction of flow is from bottom to top, scale of ruler is in millimeters.

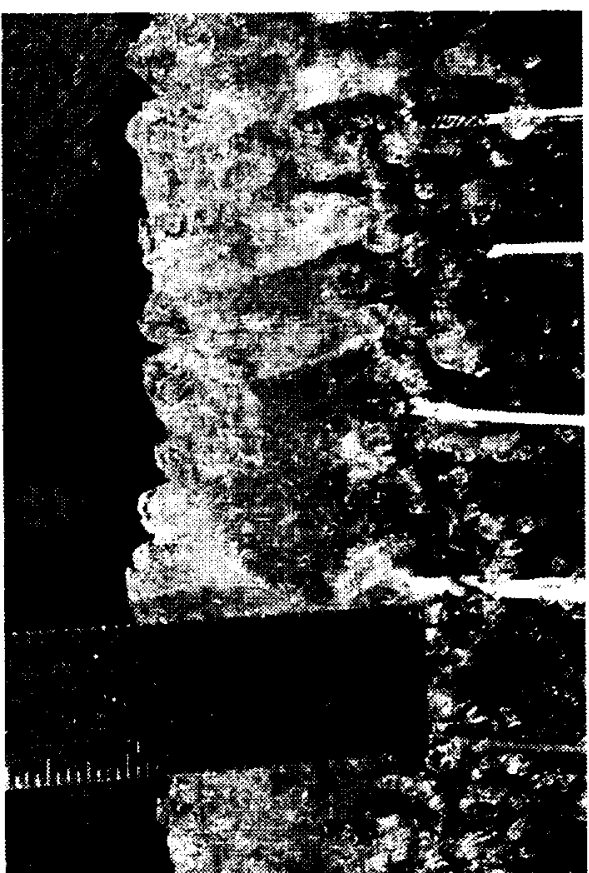

Figure 27. Side view of glaze ice feathers at 10 minutes, showing the ice of the attachment line zone covering the side of the feathers. $\Lambda=30^{\circ}, V=150 \mathrm{mph}, T=25^{\circ} \mathrm{F}, L W C=0.75 \mathrm{~g} / \mathrm{m}^{3}$, $M V D=20 \mu \mathrm{m}, \tau=10 \mathrm{~min}$. Direction of flow is from bottom to top, upper scale of ruler is in millimeters. 


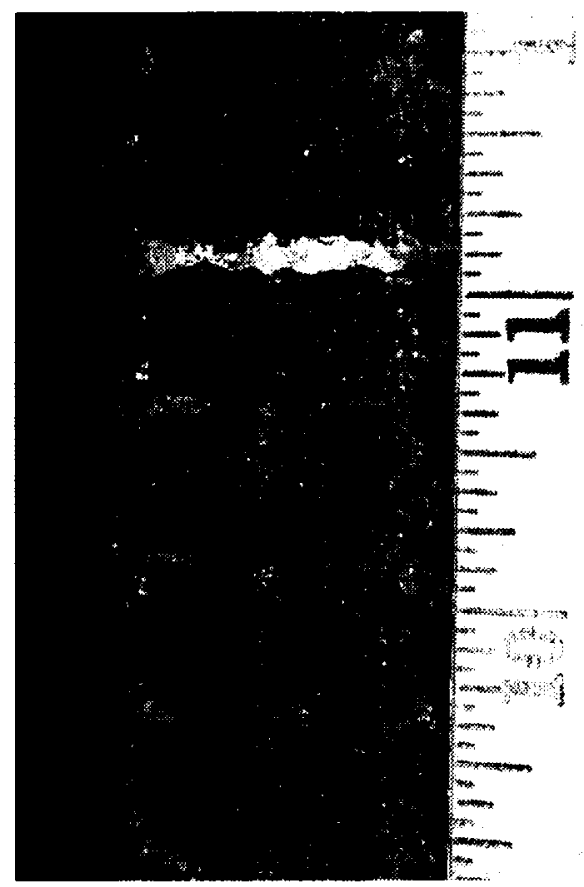

Figure 28. Front view of ice accretion at 2 minutes, showing the attachment line zone and the glaze ice feathers zone. $\quad \Lambda=15^{\circ}, V=150$ $\mathrm{mph}, T=25^{\circ} \mathrm{F}, \quad L W C=0.75 \mathrm{~g} / \mathrm{m}^{3}, \quad M V D=20 \mu \mathrm{m}$, $\tau=2 \mathrm{~min}$. Direction of flow is from bottom to top, scale of ruler is in inches.

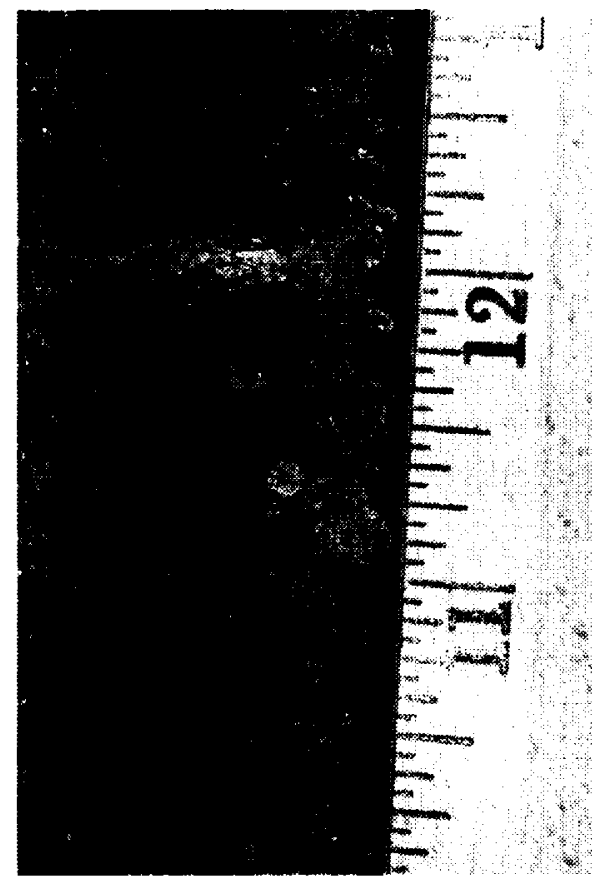

Figure 30. Close-up at ice accretion time of 5 minutes, showing the ice of the attachment line zone covering the glaze ice feathers zone. $\Lambda=15^{\circ}, V=150 \mathrm{mph}, T=25^{\circ} \mathrm{F}, \quad L W C=0.75 \mathrm{~g} / \mathrm{m}^{3}$, $M V D=20 \mu \mathrm{m}, \tau=5 \mathrm{~min}$. Direction of flow is from bottom to top, scale of ruler is in inches.

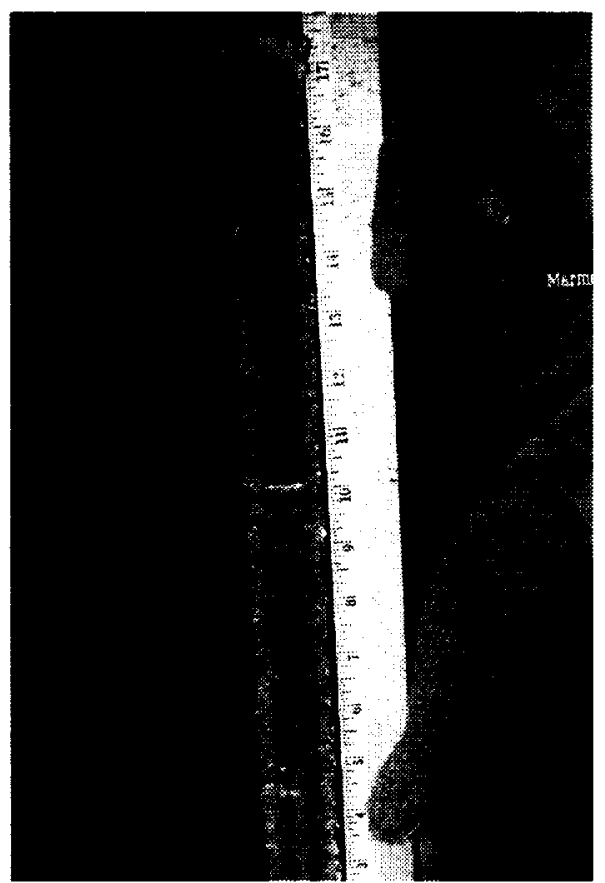

Figure 29. Front view of ice accretion at 5 minutes, showing the feathers of the glaze ice feathers zone not forming scallop tips. $\Lambda=15^{\circ}$, $V=150 \quad \mathrm{mph}, \quad T=25^{\circ} \mathrm{F}, \quad L W C=0.75 \mathrm{~g} / \mathrm{m}^{3}$, $M V D=20 \mu \mathrm{m}, \tau=5 \mathrm{~min}$. Direction of flow is from bottom to top, scale of ruler is in inches.

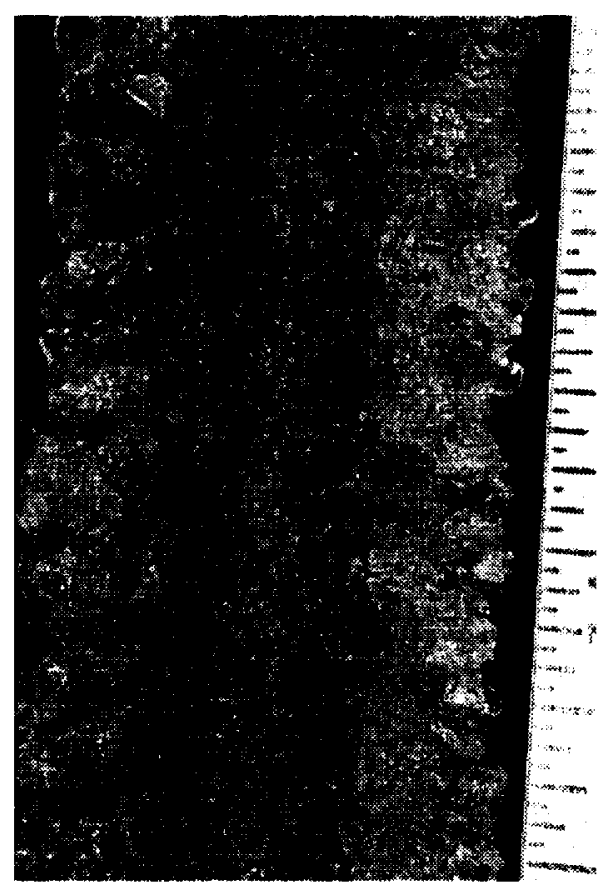

Figure 31. Close-up of ice accretion at 8 minutes. $\quad \Lambda=15^{\circ}, \quad V=150 \mathrm{mph}, \quad T=25^{\circ} \mathrm{F}$, $L W C=0.75 \mathrm{~g} / \mathrm{m}^{3}, \quad M V D=20 \mu \mathrm{m}, \quad \tau=8 \mathrm{~min}$. Direction of flow is from bottom to top, scale of ruler is in Inches. 


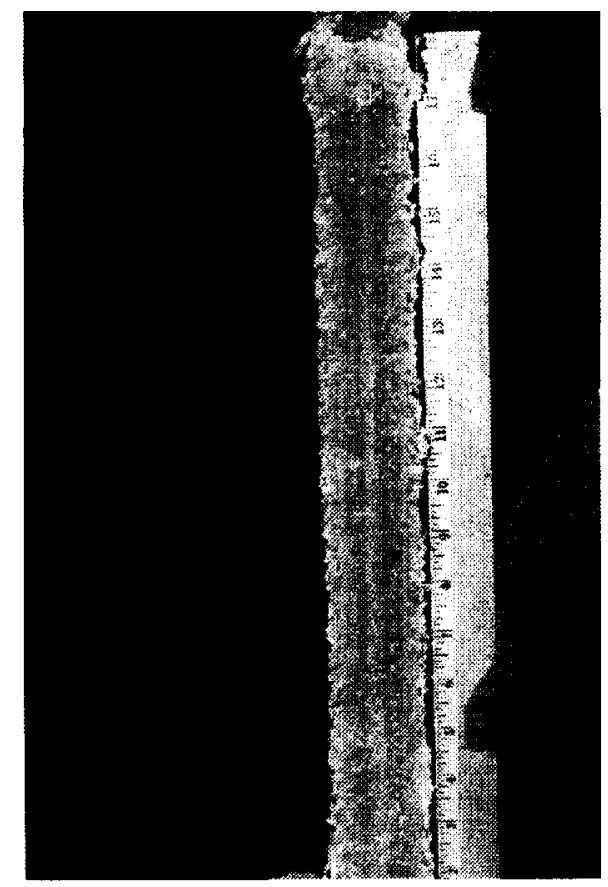

Figure 32. Front view of ice accretion at 11.6 minutes. $\Lambda=15^{\circ}, V=150 \mathrm{mph}, T=25^{\circ} \mathrm{F}$, LWC $=0.75 \mathrm{~g} / \mathrm{m}^{3}, \quad M V D=20 \mu \mathrm{m}, \quad \tau=11.6 \mathrm{~min}$. Direction of flow is from bottom to top, scale of ruler is in inches.

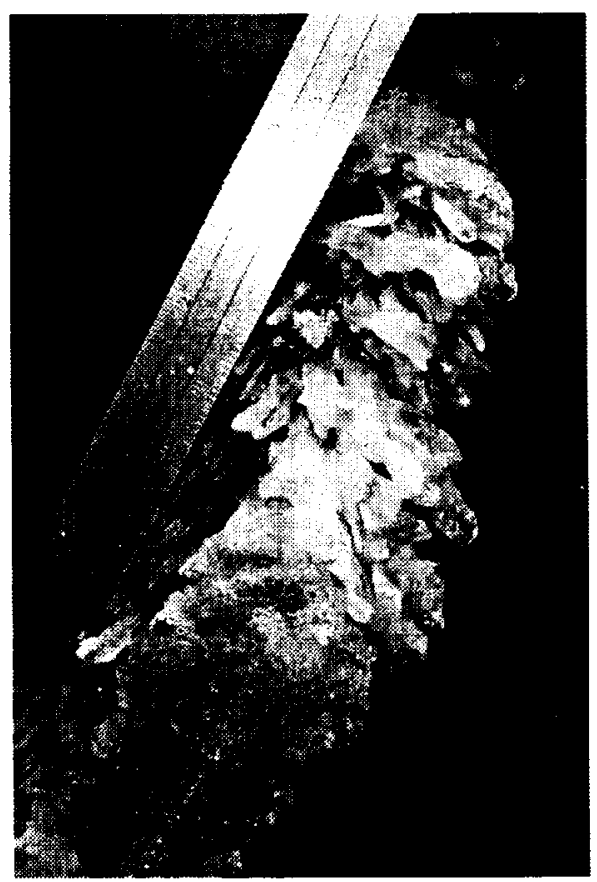

Figure 34. Special case for $15^{\circ}$ sweep angle, showing scallops on the end cap. $\Lambda=15^{\circ}$, $V=150 \mathrm{mph}, \quad T=25^{\circ} \mathrm{F}, \quad L W C=0.75 \mathrm{~g} / \mathrm{m}^{3}$, $M V D=20 \mu \mathrm{m}, \tau=5 \mathrm{~min}$. Direction of flow is from bottom to top, scale of ruler against the ice shape is in millimeters.

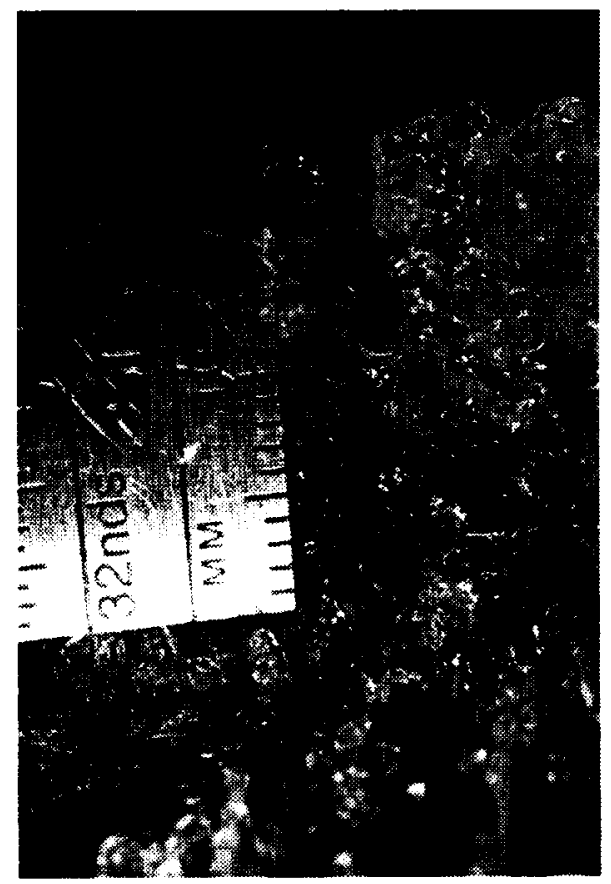

Figure 33. Side view of the glaze ice feathers zone at 11.6 minutes, showing the side of the glaze ice feathers covered with ice from the attachment line zone. $\Lambda=15^{\circ}, V=150 \mathrm{mph}$, $\mathrm{T}=25^{\circ} \mathrm{F}, \quad L W C=0.75 \mathrm{~g} / \mathrm{m}^{3}, \quad M V D=20 \mu \mathrm{m}$, $\tau=11.6 \mathrm{~min}$. Scale of ruler is in millimeters.

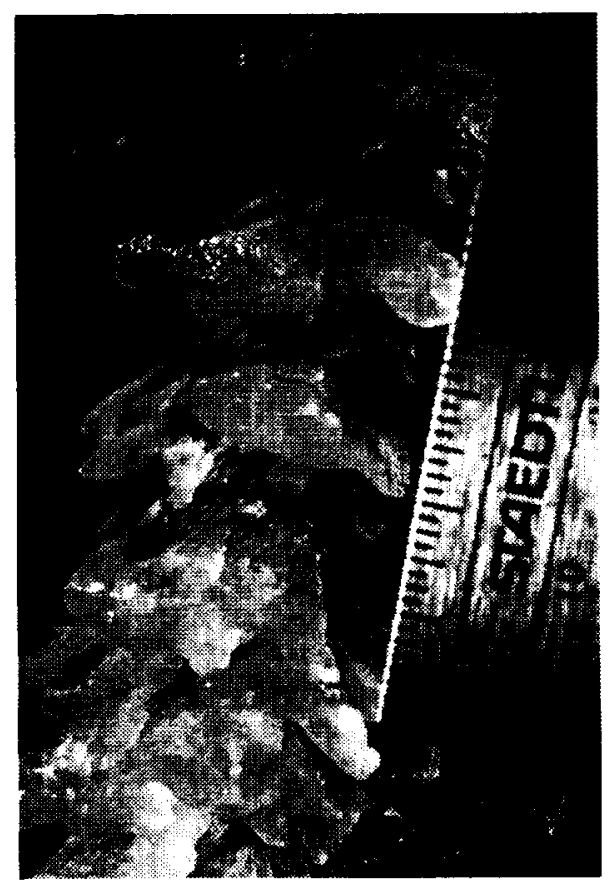

Figure 35. Special case for $15^{\circ}$ sweep angle Close-up of ridges with preferred direction of growth. $\quad \Lambda=15^{\circ}, \quad V=150 \mathrm{mph}, \quad T=25^{\circ} \mathrm{F}$, LWC $=0.75 \mathrm{~g} / \mathrm{m}^{3}, \quad M V D=20 \mu \mathrm{m}, \quad \tau=5 \mathrm{~min}$. Direction of flow is from bottom to top, scale of ruler (left side) is in inches. 


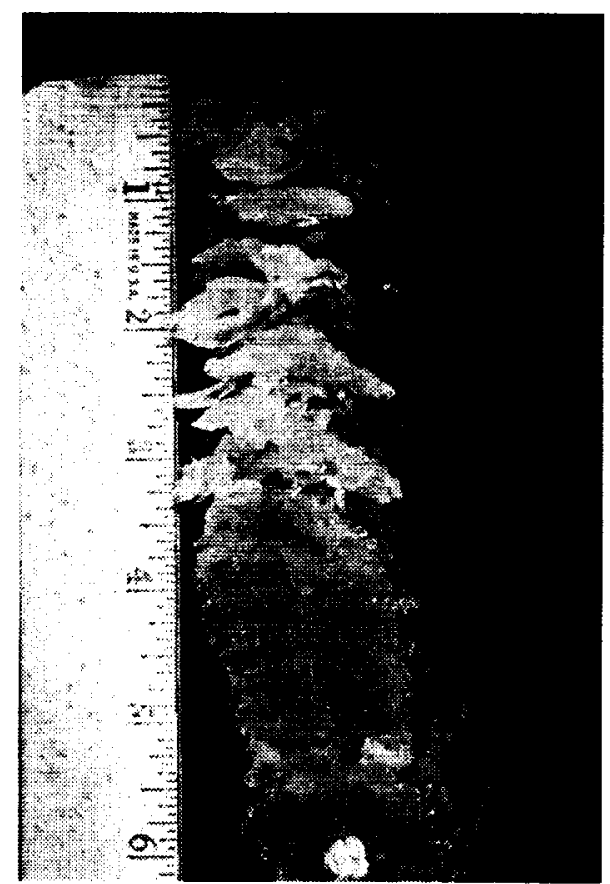

Figure 36. Special case for $15^{\circ}$ sweep angle, showing well developed scallops on the end cap at an ice accretion time of 8 minutes. $\Lambda=15^{\circ}, V=150 \mathrm{mph}, T=25^{\circ} \mathrm{F}, \quad L W C=0.75 \mathrm{~g} / \mathrm{m}^{3}$, $M V D=20 \mu \mathrm{m}, \tau=8 \mathrm{~min}$. Direction of flow is from bottom to top, scale of ruler is in inches.

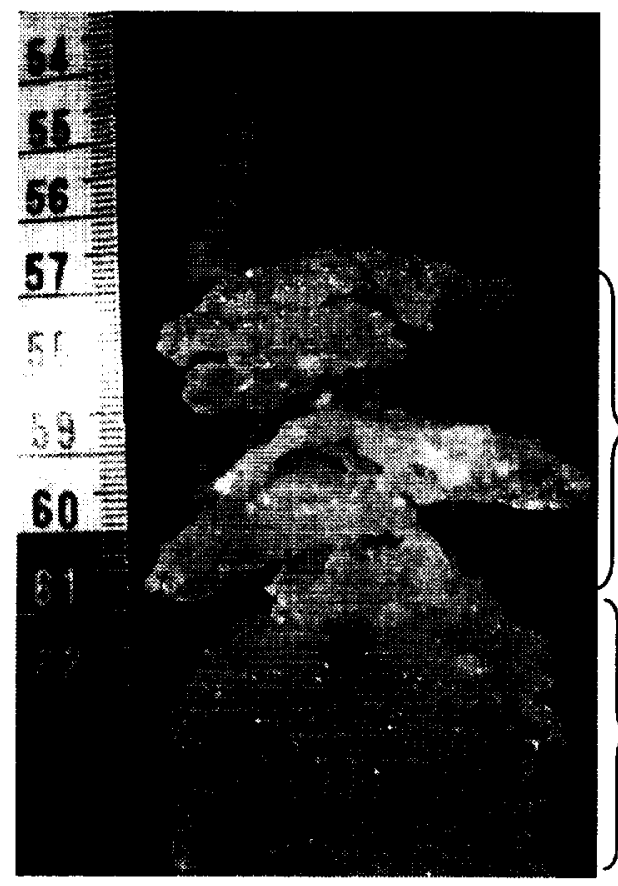

Scallops

on the

end cap

Ice

accretion

on the

leading

edge

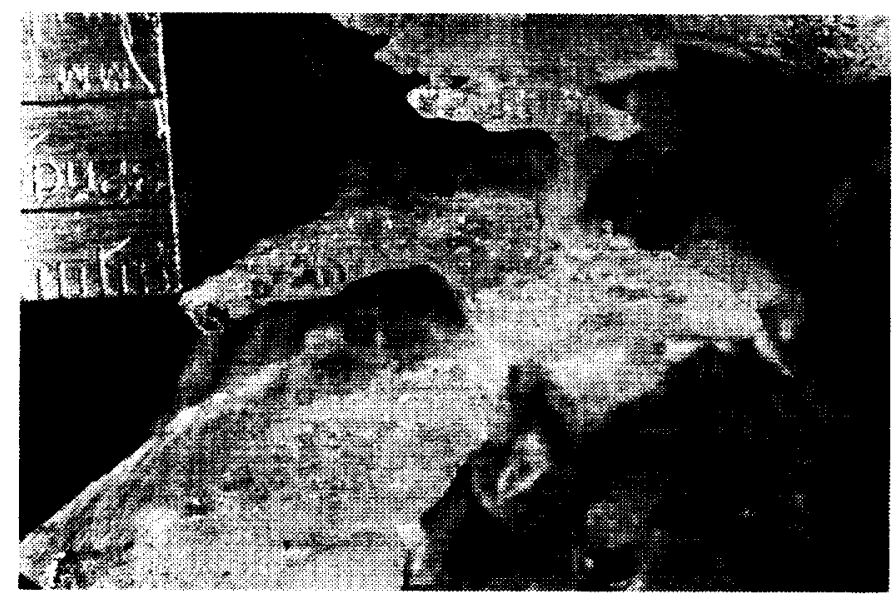

Figure 37. Special case for $15^{\circ}$ sweep angle Close-up of ridges, showing the disparity between the growth of the feathers in the preferred direction of growth (normal to the streamlines), versus growth in the direction of How. $\quad \Lambda=15^{\circ}, \quad V=150 \mathrm{mph}, \quad T=25^{\circ} \mathrm{F}$, LWC $=0.75 \mathrm{~g} / \mathrm{m}^{3}, \quad M V D=20 \mu \mathrm{m}, \quad \tau=8 \mathrm{~min}$ Direction of flow is from bottom to top, the smallest division on the lower scale is $1 / 32 n d$ of an inch.

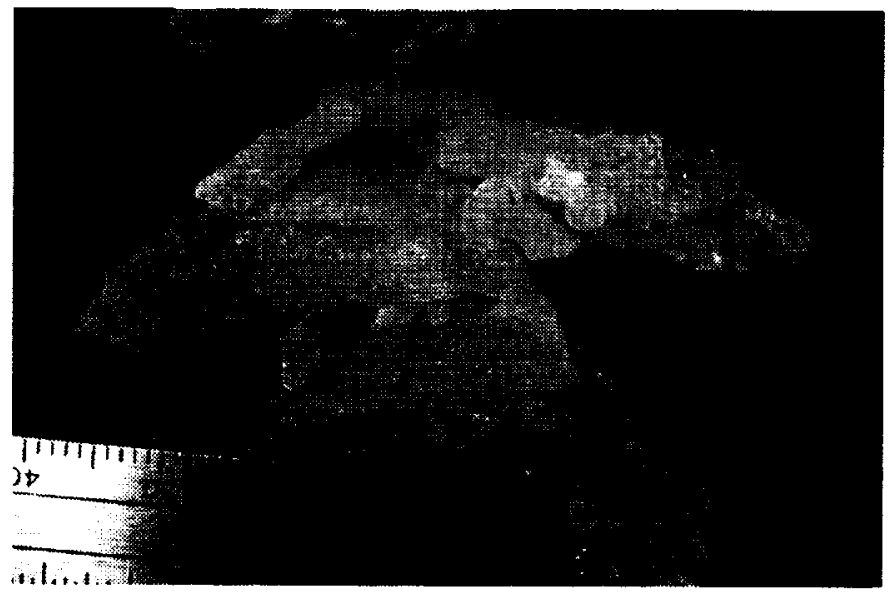

Figure 39. Special case for $15^{\circ}$ sweep angle, close-up of scallops formed on the endcap showing scallops covered with roughness elements. $\quad \Lambda=15^{\circ}, V=150 \mathrm{mph}, T=25^{\circ} \mathrm{F}$, LWC $=0.75 \mathrm{~g} / \mathrm{m}^{3}, \quad M V D=20 \mu \mathrm{m}, \quad \tau=11.6 \mathrm{~min}$ Direction of flow is from bottom to top, scale of ruler is in millimeters. 


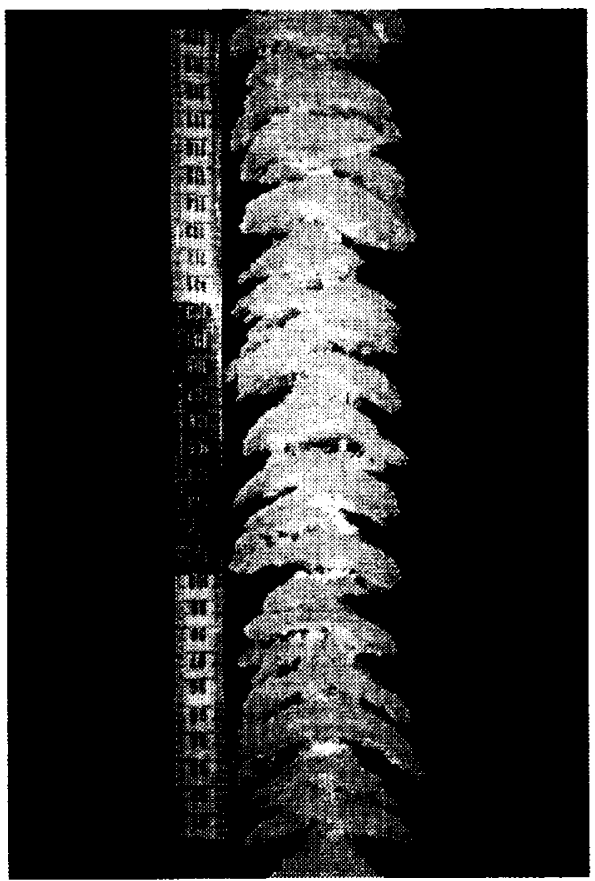

Figure 40. Fully developed scallops at 250 mph. $\quad \Lambda=45^{\circ}, \quad V=250 \quad \mathrm{mph}, \quad T=25^{\circ} \mathrm{F}$, LWC $=0.75 \mathrm{~g} / \mathrm{m}^{3}, \quad M V D=20 \mu \mathrm{m}, \quad \tau=10 \mathrm{~min}$. Direction of flow is from bottom to top, scale of ruler is in centimeters.

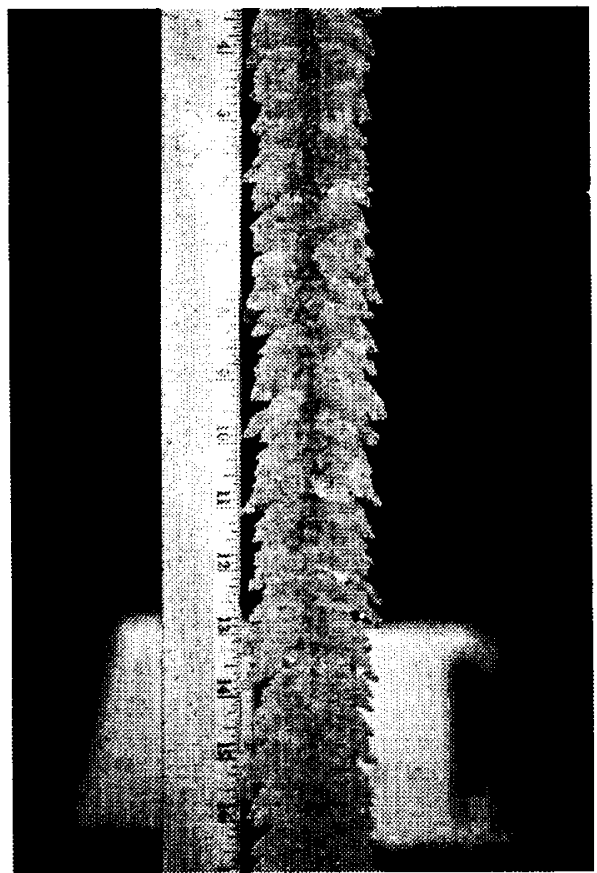

Figure 42. Nearly complete scallops at 200 mph. $\quad \Lambda=30^{\circ}, \quad V=200 \mathrm{mph}, T=25^{\circ} \mathrm{F}$ $L W C=0.75 \mathrm{~g} / \mathrm{m}^{3}, \quad M V D=20 \mu \mathrm{m}, \quad \tau=10 \mathrm{~min}$. Direction of flow is from bottom to top, scale of ruler is in inches.

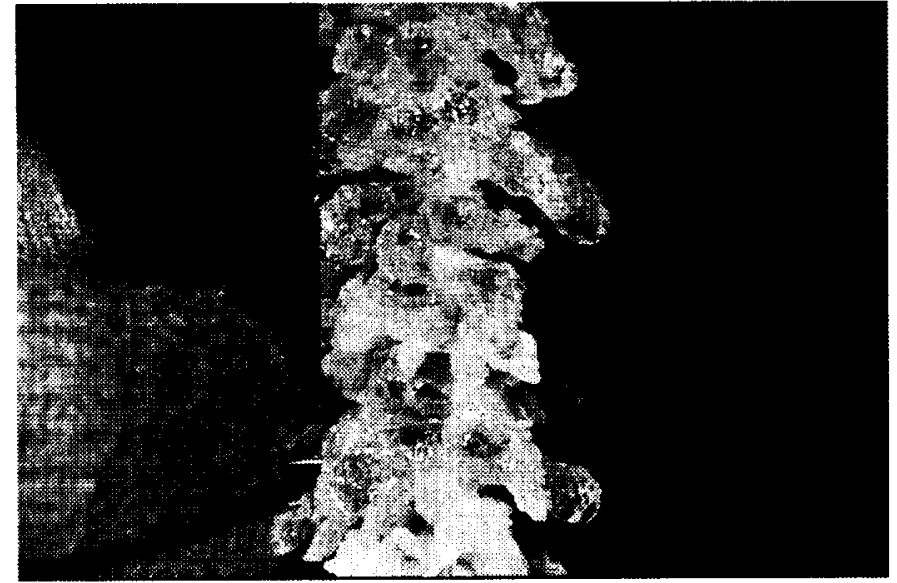

Figure 41. Scallops at $100 \mathrm{mph} . \quad \Lambda=45^{\circ}$, $V=100 \quad \mathrm{mph}, \quad T=25^{\circ} \mathrm{F}, \quad L W C=0.75 \mathrm{~g} / \mathrm{m}^{3}$, $M V D=20 \mu \mathrm{m}, \tau=15 \mathrm{~min}$. Direction of flow is from bottom to top, scale of ruler on (on the right side) is in millimeters.

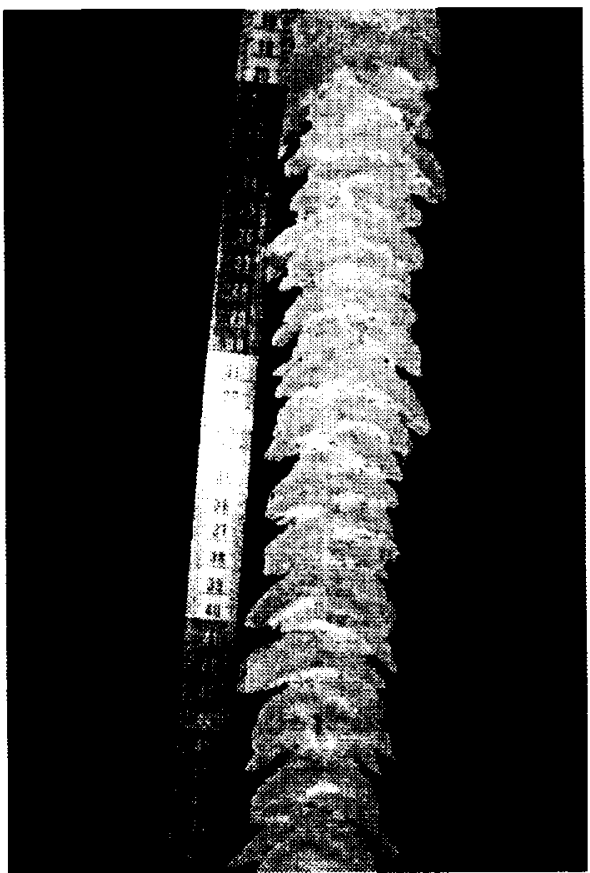

Figure 43. Complete scallops at $250 \mathrm{mph}$. $\Lambda=30^{\circ}, V=250 \mathrm{mph}, T=25^{\circ} \mathrm{F}, L W C=0.75 \mathrm{~g}^{\mathrm{m}} \mathrm{m}^{3}$, $M V D=20 \mu \mathrm{m}, \tau=10 \mathrm{~min}$. Direction of flow is from bottom to top, scale of ruler is in centimeters. 


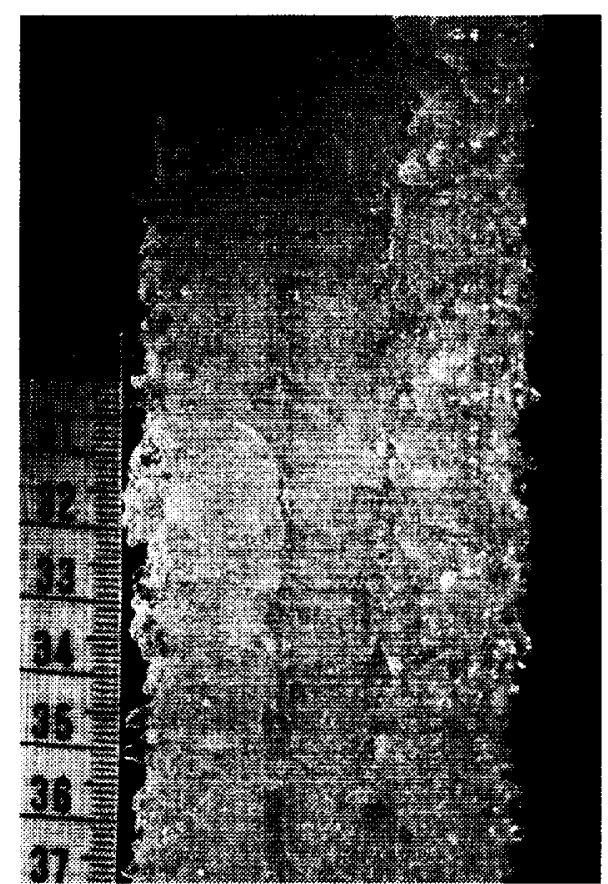

Figure 44. Attachment line zone and glaze ice feathers zone at $200 \mathrm{mph} . \Lambda=15^{\circ}, V=200 \mathrm{mph}$, $\mathrm{T}=25^{\circ} \mathrm{F}, \mathrm{LWC}=0.75 \mathrm{~g} / \mathrm{m}^{3}, M V D=20 \mu \mathrm{m}, \tau=10 \mathrm{~min}$. Direction of flow is from bottom to top, scale of ruler is in centimeters.

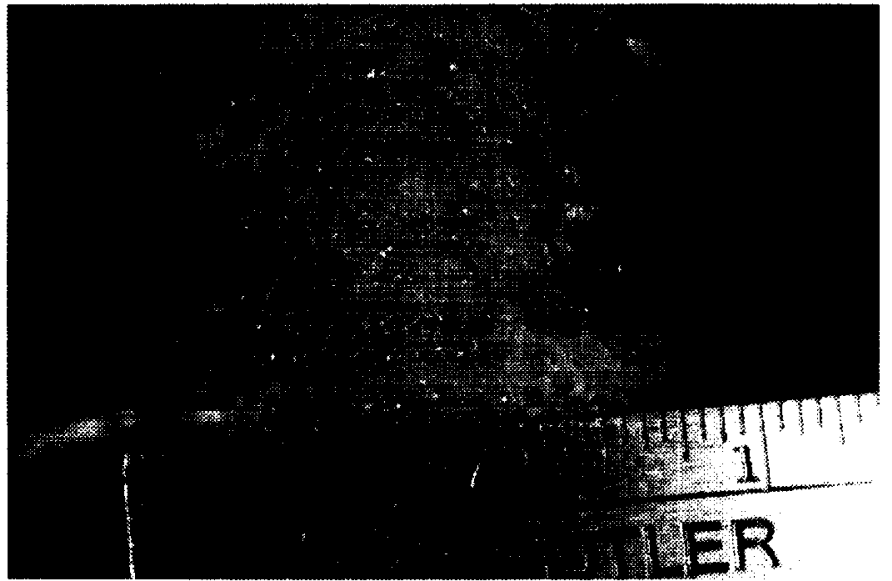

Figure 46. Ice accretion at a temperature of $20^{\circ} \mathrm{F}$, showing the feathers on the attachment line area. $\Lambda=45^{\circ}, V=150 \mathrm{mph}, T=20^{\circ} \mathrm{F}$, $L W C=0.75 \mathrm{~g} / \mathrm{m}^{3}, \quad M V D=20 \mu \mathrm{m}, \quad \tau=2 \mathrm{~min}$. Direction of flow is from bottom to top, scale of ruler is in inches.

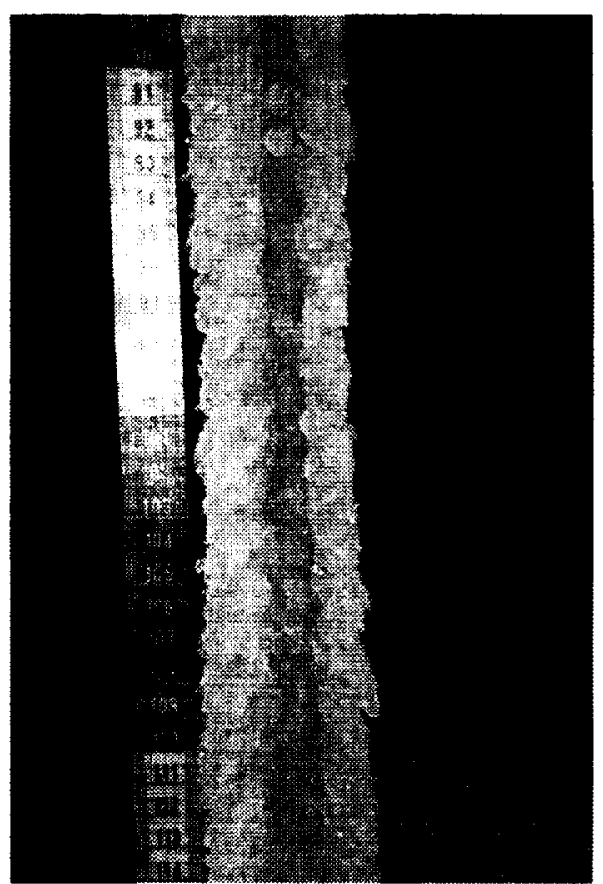

Figure 45. Ice accretion at $250 \mathrm{mph} . \quad \Lambda=15^{\circ}$, $V=250 \quad \mathrm{mph}, \quad T=25^{\circ} \mathrm{F}, \quad \mathrm{LWC}=0.75 \mathrm{~g} / \mathrm{m}^{3}$, $M V D=20 \mu \mathrm{m}, \tau=10 \mathrm{~min}$. Direction of flow is from bottom to top, scale of ruler is in centimeters.

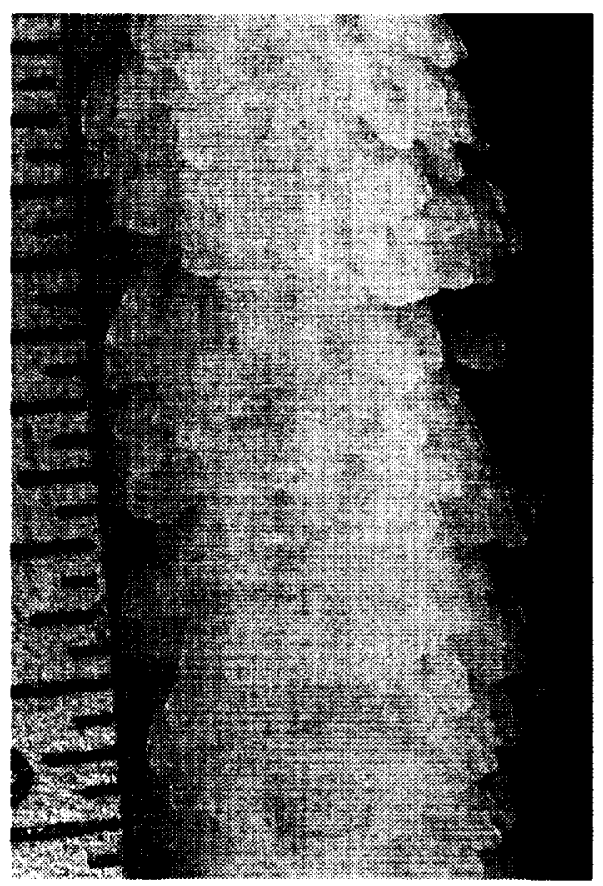

Figure 47. Ice accretion at a temperature of $20^{\circ} \mathrm{F}$, showing inclpient scallop tips. $\Lambda=45^{\circ}$, $V=150 \quad \mathrm{mph}, \quad T=20^{\circ} \mathrm{F}, \quad L W C=0.75 \mathrm{~g} / \mathrm{m}^{3}$, $M V D=20 \mu \mathrm{m}, \tau=10 \mathrm{~min}$. Direction of flow is from bottom to top, smallest division on the scale is $1 / 16$ th of an inch. 


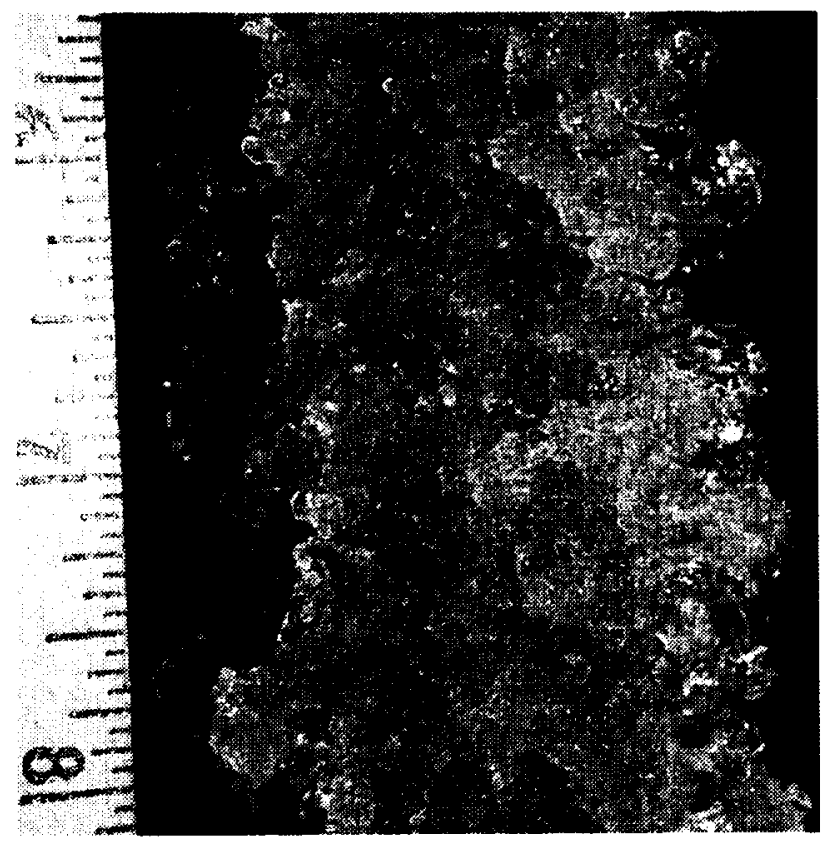

Figure 48. Close-up of ice accretion at a temperature of $29^{\circ} \mathrm{F} . \quad \Lambda=30^{\circ}, V=150 \mathrm{mph}$, $T=29^{\circ} \mathrm{F}, L W C=0.75 \mathrm{~g} / \mathrm{m}^{3}, M V D=20 \mu \mathrm{m}, t=10 \mathrm{~min}$ Direction of flow is from bottom to top, scale of ruler is in inches.

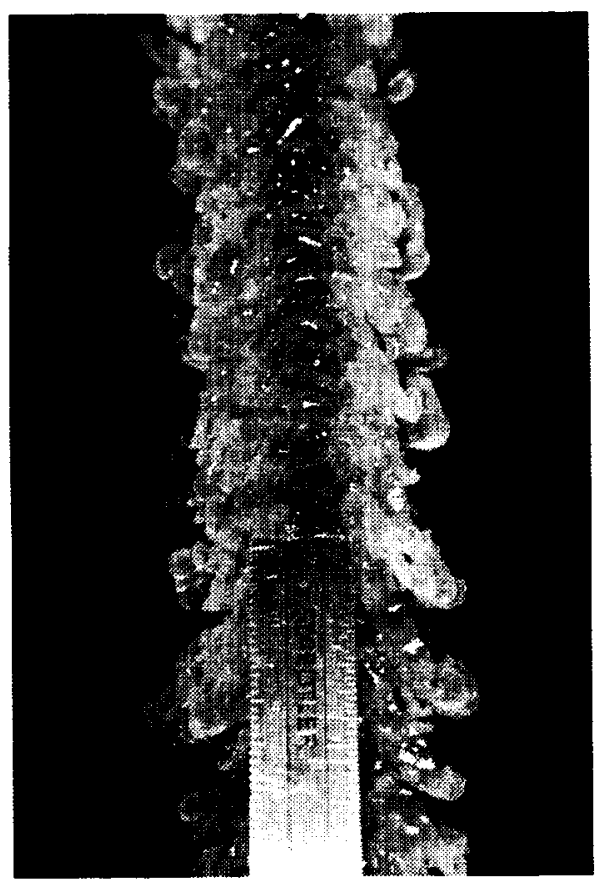

Figure 50. Ice accretion at a LWC of $0.5 \mathrm{~g} / \mathrm{m}^{3}$. $\Lambda=30^{\circ}, V=150 \mathrm{mph}, T=25^{\circ} \mathrm{F}, \quad L W C=0.5 \mathrm{~g} / \mathrm{m}^{3}$, $M V D=20 \mu \mathrm{m}, \tau=10 \mathrm{~min}$. Direction of flow is from bottom to top, scale of ruler is in millimeters on the left, inches on the right.

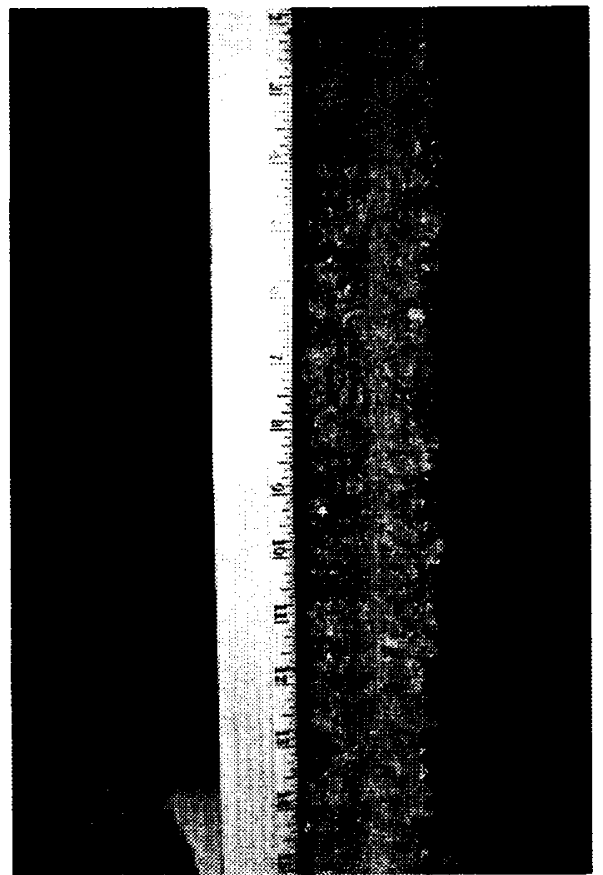

Figure 49. Front view of ice accretion at a temperature of $29^{\circ} \mathrm{F} . \quad \Lambda=15^{\circ}, V=150 \mathrm{mph}$, $\mathrm{T}=29^{\circ} \mathrm{F}, \mathrm{LWC}=0.75 \mathrm{~g} / \mathrm{m}^{3}, M V D=20 \mu \mathrm{m}, \tau=10 \mathrm{~min}$. Direction of flow is from bottom to top, scale of ruler is in inches.

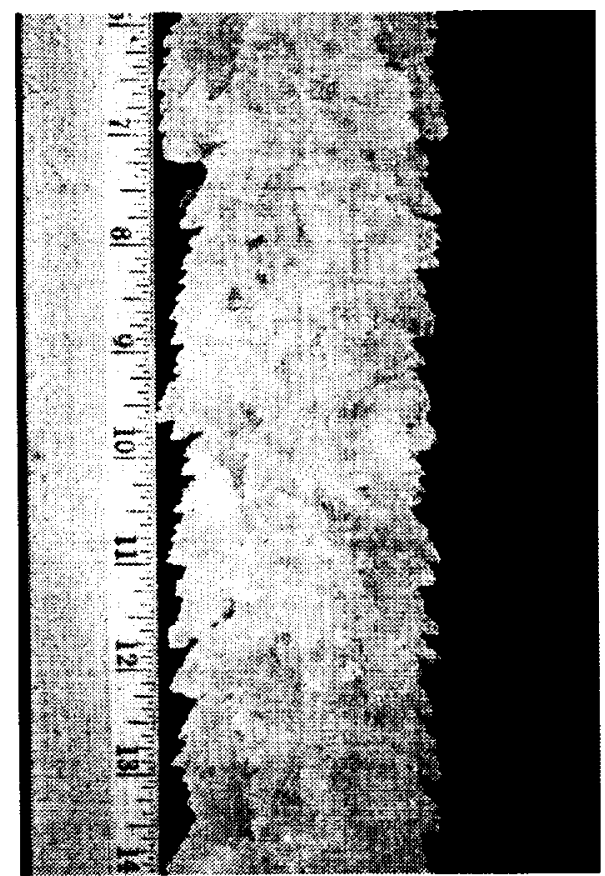

Figure 51. Ice accretion at a $L W C$ of $1.25 \mathrm{~g} / \mathrm{m}^{3}$. $\Lambda=30^{\circ}, V=150 \mathrm{mph}, T=25^{\circ} \mathrm{F}, \quad L W C=1.25 \mathrm{~g} / \mathrm{m}^{3}$, $M V D=20 \mu \mathrm{m}, \tau=10 \mathrm{~min}$. Direction of flow is from bottom to top, scale of ruler is in inches. 


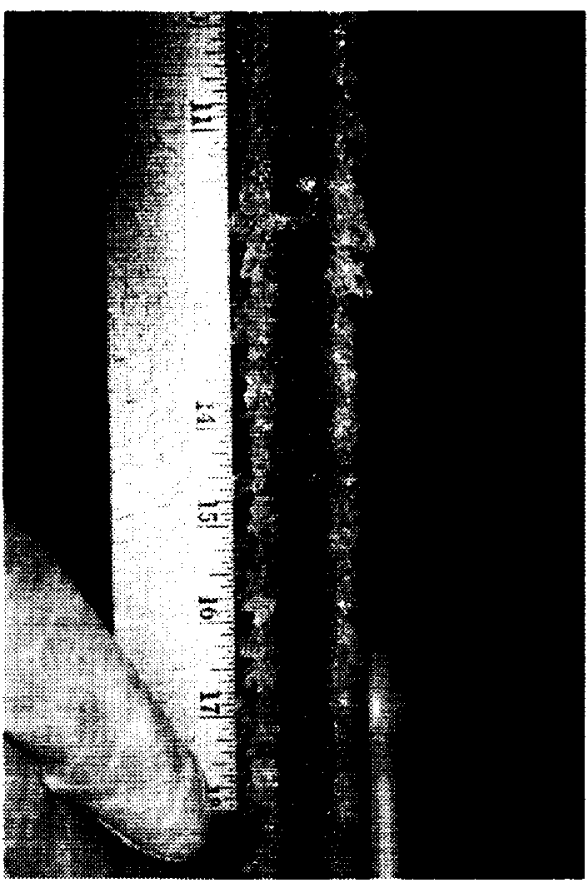

Figure 52. Ice accretion at a $L W C$ of $0.5 \mathrm{~g} / \mathrm{m}^{3}$. The attachment line zone and the glaze ice feathers zone can be observed. $\Lambda=15^{\circ}, V=150$ $\mathrm{mph}, \quad T=25^{\circ} \mathrm{F}, \quad L W C=0.5 \mathrm{~g} / \mathrm{m}^{3}, \quad M V D=20 \mu \mathrm{m}$, $\tau=10 \mathrm{~min}$. Direction of flow is from bottom to top, scale of ruler is in inches.

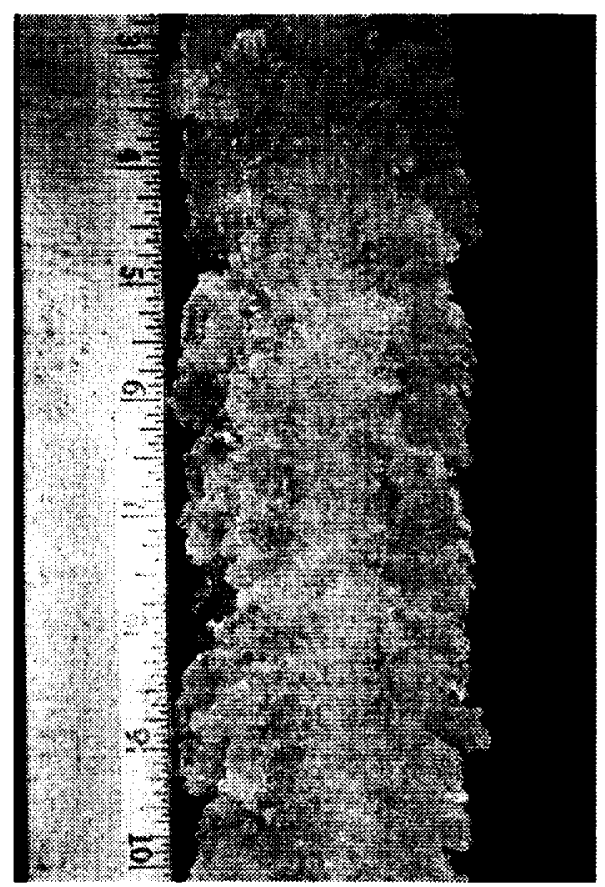

Figure 53. Ice accretion at a $L W C$ of $1.25 \mathrm{~g} / \mathrm{m}^{3}$. $\Lambda=15^{\circ}, V=150 \mathrm{mph}, T=25^{\circ} \mathrm{F}, L W C=1.25 \mathrm{~g} / \mathrm{m}^{3}$, $M V D=20 \mu \mathrm{m}, \tau=10 \mathrm{~min}$. Direction of flow is from bottom to top, scale of ruler is in inches.

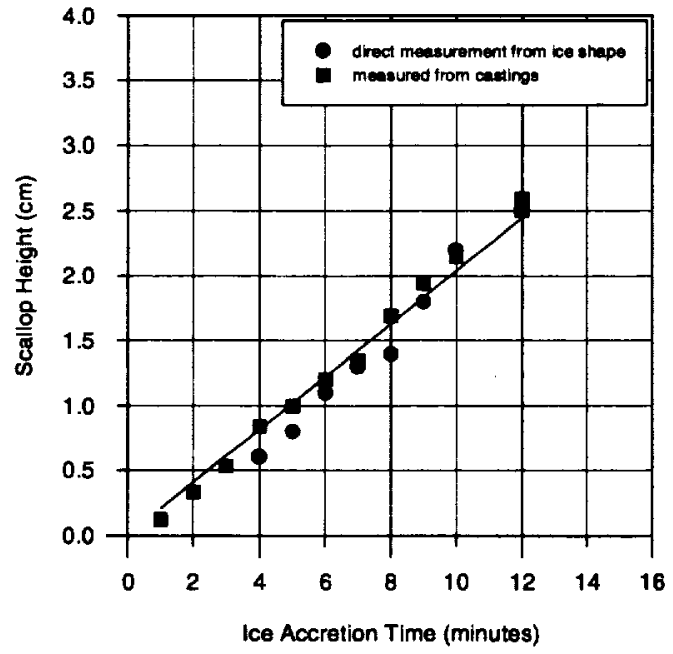

Figure 54. Change in scallop height with ice accretion time. $\Lambda=45^{\circ}, V=150 \mathrm{mph}, T=25^{\circ} \mathrm{F}$, $L W C=0.75 \mathrm{~g} / \mathrm{m}^{3}, M V D=20 \mu \mathrm{m}$.

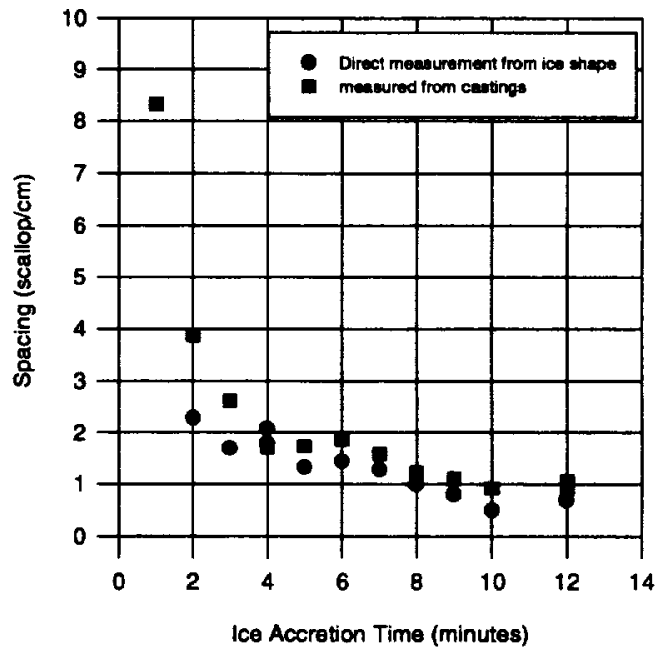

Flgure 55. Change in scallop spacing with ice accretion time. $\Lambda=45^{\circ}, V=150 \mathrm{mph}, T=25^{\circ} \mathrm{F}$, $L W C=0.75 \mathrm{~g} / \mathrm{m}^{3}, M V D=20 \mu \mathrm{m}$. 


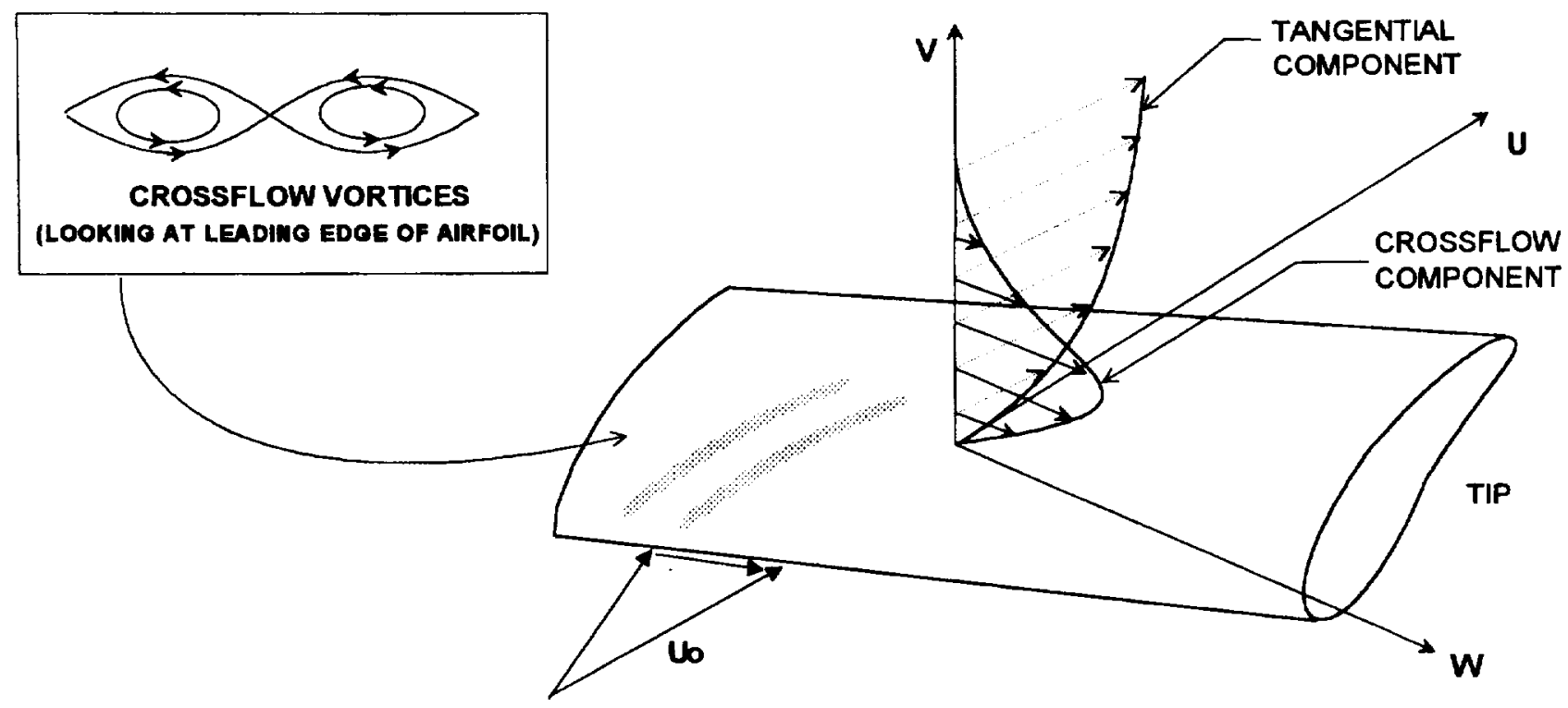

Figure 56. Crossflow Instability 


\begin{tabular}{|c|c|c|}
\hline \multicolumn{2}{|c|}{ REPORT DOCUMENTATION PAGE } & $\begin{array}{l}\text { Form Approved } \\
\text { OMB No. 0704-0188 }\end{array}$ \\
\hline \multicolumn{3}{|c|}{ 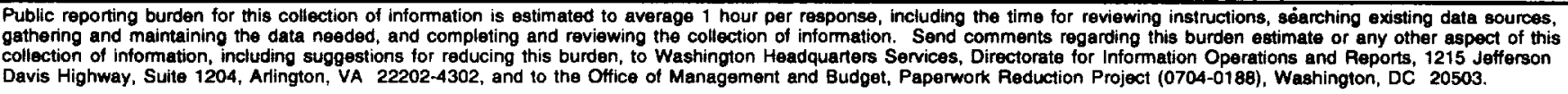 } \\
\hline 1. AGENCY USE ONLY (Leave blank) & $\begin{array}{l}\text { 2. REPORT DATE } \\
\text { January } 1998\end{array}$ & $\begin{array}{l}\text { D DATES COVERED } \\
\text { echnical Memorandum }\end{array}$ \\
\hline $\begin{array}{l}\text { 4. TITLE AND SUBTITLE } \\
\text { Physical Mechanisms of Gle }\end{array}$ & ce Scallop Formations on Swept $\mathrm{V}$ & 5. FUNDING NUMBERS \\
\hline $\begin{array}{l}\text { 6. AUTHOR(S) } \\
\text { Mario Vargas and Eli Resho }\end{array}$ & & WU-548-20-23-00 \\
\hline \multicolumn{2}{|c|}{$\begin{array}{l}\text { National Aeronautics and Space Administration } \\
\text { Lewis Research Center } \\
\text { Cleveland, Ohio } 44135-3191\end{array}$} & $\begin{array}{l}\text { 8. PERFORMING ORGANIZATION } \\
\text { REPORT NUMBER } \\
\text { E-11037 }\end{array}$ \\
\hline $\begin{array}{l}\text { 9. SPONSORING/MONITORING AGE } \\
\text { National Aeronautics and } S_{\mathrm{F}} \\
\text { Washington, DC } 20546-00\end{array}$ & $\begin{array}{l}\text { VAME(S) AND ADDRESS(ES) } \\
\text { Administration }\end{array}$ & $\begin{array}{l}\text { 10. SPONSORINGMONITORING } \\
\text { AGENCY REPORT NUMBER } \\
\text { NASA TM-1998-206616 } \\
\text { AIAA-98-0491 }\end{array}$ \\
\hline
\end{tabular}

\section{SUPPLEMENTARY NOTES}

Prepared for the 36th Aerospace Sciences Meeting \& Exhibit sponsored by the American Institute of Aeronautics and Astronautics, Reno, Nevada, January 12-15, 1998. Mario Vargas, NASA Lewis Research Center and Eli Reshotko, Case Western Reserve University, Cleveland, Ohio 44106. Responsible person, Mario Vargas, organization code 5840, (216) 433-2064.

\section{2a. DISTRIBUTION/AVAILABILITY STATEMENT} 12b. DISTRIBUTION CODE

Unclassified - Unlimited

Subject Categories: 01 and 02

Distribution: Nonstandard

This publication is available from the NASA Center for AeroSpace Information, (301) 621-0390.

13. ABSTRACT (Maximum 200 words)

An experiment was conducted to understand the physical mechanisms that lead to the formation of scallops on swept wings. Icing runs were performed on a NACA 0012 swept wing tip at $45^{\circ}, 30^{\circ}$, and $15^{\circ}$ sweep angles. A baseline case was chosen and direct measurements of scallop height and spacing, castings, video data and close-up photographic data were obtained. The results showed the scallops are made of glaze ice feathers that grow from roughness elements that have reached a minimum height and are located beyond a given distance from the attachment line. This distance depends on tunnel conditions and sweep angle, and is the critical parameter in the formation of scallops. It determines if complete scallops, incomplete scallops or no scallops are going to be formed. The mechanisms of growth for complete and incomplete scallops were identified. The effect of velocity, temperature and LWC on scallop formation was studied. The possibility that cross flow instability may be the physical mechanism that triggers the growth of roughness elements into glaze ice feathers is examined.

\section{SUBJECT TERMS}

Icing; Swept wings; Ice scallop formations; Lobster tails; Cross flow vortices; Cross flow instability; Swept wing ice accretions

17. SECURITY CLASSIFICATION
OF REPORT
Unclassified

NSN 7540-01-280-5500

18. SECURTY CLASSIFICATION
OF THIS PAGE
Unclassified

Unclassified

19. SECUAITY CLASSIFICATION
OF ABSTAACT
Unclassified

15. NUMBER OF PAGES
37
16. PRICE CODE
A03
20. LIMITATION OF ABSTRACT
ndard Form 298 (Rev. 2-89)
scribed by ANSI Std. Z39-18

Prescribed by ANSI Sid. Z39-18 298-102 